\title{
THE SIGNIFICANCE OF THE PRINCIPLE OF EQUALITY IN THE CONFLICT OF LAWS
}

\author{
WILHELM WENGLER*
}

The present paper will discuss the significance of the principle of equality for the conflict of laws as a policy guideline, a rule of public international law, or a rule of internal constitutional law.

\section{The Equal Treatment of the Substantive Laws of Different States}

It is relatively easy to determine the significance of the postulate that the substantive laws of the various states which are made applicable by the forum's choiceof-law rules have to receive equal treatment. One way to achieve this is to establish the same criteria for the applicability of foreign and domestic law, e.g., by uniformly subjecting succession to the law of the nationality or the domicile of the decedent, or to the lex rei sitae. This treatment of the lex fori and of foreign legal systems on the basis of parity ${ }^{1}$ is generally the product of so-called multilateral choice-of-law rules. The same result can, however, be achieved by delimiting the applicability of the lex fori by a unilateral choice-of-law rule and leaving the regulation of the applicability of foreign substantive law to foreign choice-of-law rules in such a manner that the interplay of the domestic and the foreign rules results in parity of treatment for the foreign and domestic legal orders. ${ }^{2}$

Unequal consideration of foreign and domestic law is usually the result of a more extensive application of the lex fori. This is almost invariably the case where the foreign substantive law rules that are "normally" applicable are excluded from application on grounds of public policy, and where the gap thus created is filled by domestic law. Inequality also results, obviously, where foreign law is applicable only if connecting factor $A$ is present and $B$ is not, while the lex for $i$ applies in the presence of either factor $A$ or factor $B$. An example of this would be the application of the forum's substantive law of succession to the estates of all decedents who are nationals of the forum state, and of the lex domicilii to the estates of all non-nationals: ${ }^{3}$ Foreign law would then only be applicable to the estates of aliens domiciled abroad. Another common example is the applicability of the forum's law of marital property

- Dr. iur., Dr. rer. pol., University of Frankfurt, r93r. Professor of Law and Director, Institute of International and Comparative Law, Free University of Berlin. (Editor's Note: The author did not have the opportunity to check the accuracy of my translation of this article from the German.)

${ }^{1} \mathrm{Sec}$, in this connection, especially Vallindas, La structure de la règle de confit, ror Académe DE Droit International, Recueil des Cours 329, 343-44 (I960-III), and Jean Marc Bischofr, LA COMPÉTENCE DU DROIT FRANÇAIS DANS LE RÈGLEMENT DES CONFLITS DE LOIS (I959).

'See, e.g., articles 24 and 25 of the Introductory Law to the German Civil Code [hercinafter cited as EGBGB]. (Editor's Note: the texts of the statutory choice-of-law rules referred to in this note and in subsequent notes can be found in 1 ALEXander $N$. Makarov, Quellen zum Internationalen Privatrecht (2d ed. 1953 et seq.)).

${ }^{3}$ See, e.g., article VIII of the Introductory Provisions of the Civil Code of Peru. 
when one of the spouses is a national of the forum state; ${ }^{4}$ here, foreign law applies only if both spouses are aliens.

A variation of this preference for the lex fori is a choice-of-law rule that makes the applicability of the forum's law in derogation of the normal conflicts rule contingent upon the act of a party or on the results of the application of foreign or domestic law. For instance, a choice-of-law rule might provide that succession is generally governed by the law of the nationality of the decedent, but that an heir who is a national of the forum state can demand the application of the lex fori if he deems the latter to be more favorable. ${ }^{5}$ Or a gift is in principle governed by the national law of the donor, but the lex fori is applied to gifts by aliens in the forum state to nationals of the latter if such gifts are valid under the lex loci but not under the lex causae. ${ }^{6}$ Another, quite important example of this preferred position of the lex fori is a rule subjecting the legal capacity of the forum's own nationals to their national law irrespective of the place of the transaction, and applying the lex for $i$ to the legal capacity of aliens with respect to transactions in the forum state if the latter's law validates the transaction ${ }^{7}$-possibly with the further refinement that such validation applies only to transactions between nationals and aliens where the former assert the validity of the transaction. In all of these cases, not only is there a discrimination between foreign and domestic law, but also between nationals and aliens, or similar situations are treated in an unequal manner. ${ }^{8}$

Conceivably, the extension of the preferential reach of the lex fori might be conditioned upon the presence of foreign choice-of-law rules that the forum state deems objectionable. Thus, German private international law might refuse to apply the national law of the decedent whose last domicile was in Germany, if that law does not apply German substantive law to the succession of German domiciliaries resident in the decedent's state of nationality, and if a German heir would be favored by the applicability of German inheritance law.

Inequality between foreign and domestic law frequently results from change of status. For example, under German private international law, the law of the father's nationality generally governs his relations to his children; but if both father and child were originally German nationals and only the father acquires a foreign nationality, German law continues to apply as long as the child remains German. There is no corresponding provision for the converse case where the father acquires German nationality and the child remains an alien: here, German law becomes applicable as soon as the father becomes a German national. ${ }^{10}$

There can also be inequality of treatment between foreign and domestic law in the determination of pre-conditions to the existence of legal relationships, or of

'See, e.g., article $\mathrm{I} 4$ of the Egyptian Civil Cade.

SSee, e.g., article 2 of the French law of July 14, I819; article 25 EGBGB.

- See, e.g., section 35 of the Austrian Civil Code; cf. infra p. 832 .

${ }^{7}$ See, e.g., article 7 , section 3 EGBGB.

${ }^{8}$ With respect to the former type of discrimination, see infra p. 829 et seq.; as to the latter, p. 835 et seq.

'See, e.g., article 25 EGBGB, second sentence.

${ }^{10} \mathrm{See}$, e.g., article $19 \mathrm{EGBGB}$, as interpreted by German courts. 
matters incidental thereto. Thus, conceivably, under the forum's law of succession; adopted children might inherit from their adoptive parents only if adopted in accordance with the lex fori, even if there are no substantial differences between the foreign and the domestic adoption or even succession statutes. ${ }^{11}$ On the other hand, there would be equality between foreign and domestic adoptions as regards succession if those foreign adoptions that are the reasonable equivalents of adoptions under the forum's internal law are recognized as valid by the choice-of-law rule that governs successions. An additional requirement that the lex adoptionis have provisions regarding succession that are equivalent to those of the ultimate lex successionis, would also not be incompatible with the postulate of the equal treatment of private law systems.

If the private international law of the forum is taken to refer to the whole law of foreign jurisdictions, it is possible that this may also result in an unequal treatment of foreign legal orders as between themselves, without a necessary enlargement of the scope of the lex fori. If the forum refers to State $A$ whose choice-of-law rules in turn refer to the law of State $B$, the forum enlarges the scope of the external reach of the substantive law of State $B$ at the expense of State $A$. Still, the dislocations in the respective scopes of legal orders caused by reference to the whole law cannot as such be regarded as discriminatory. Discrimination can, however, be seen in the fact that the forum is not asking all foreign legal systems whether they are interested in regulating the case at hand, but restricts such inquiry to the choice-of-law rules of the state of initial reference.

One can ask whether the unequal treatment of foreign law, or of foreign legal systems as between each other, is compatible with the public international law principle of the equality of states. The fact that the choice-of-law rules of many states contain such inequalities and that these have to date not given rise to diplomatic protests, indicates that such a practice is not violative of international law. ${ }^{12}$ Objections based on public international law seem even less pertinent where a state enacts "equal" choice-of-law rules which, as a practical matter, enlarge the incidence of the applicability of the lex fori-as where a country with strong emigration and insignificant immigration adopts the nationality principle while, conversely, a typical country of immigration espouses the lex domicilii. ${ }^{13}$

${ }^{11}$ Sec, e.g., In Re Wilby, [1956] P. I74. Discrimination against foreign law is camouflaged if a certain legal relationship governed by the lex fori, such as the obligation to support, depends upon the existence of a "marriage"- - ostensibly without distinction between marriages valid under the lex fori and under the appropriate foreign law, but subject to the condition that the marriage be a "Christian marriage." Rules of this type can be found in some Anglophonic jurisdictions. They surcly amount to discriminations against foreign law, at least if the effect denied to the non-Christian marriage is not peculiar to Christian marriages.

${ }^{19}$ However, a treaty might prohibit discriminations between foreign legal systems inter se. Article VIII, section 3 of the German-Iranian Convention Regarding Residence, of February I7, I929, xxI L.N.T.S. $24 \mathrm{r}, 246$, provides that the nationals of one of the contracting parties within the territory of the other shall be subject to their respective national laws. Exceptions from this rule are permissible only if they apply to all third states as well.

${ }^{18}$ Nevertheless, the employment of such policy considerations in the drafting of choice-of-law rules is condemned by the Institut de Droit international in its Resolution of April 25, 1952, 44 ANwusirz DE L'TNstitut DE Droit international pt. 2, at 477 (I952). 
On the other hand, an unequal treatment of different legal systems effective within one country resulting from the application of interregional or interpersonal choice-of-law rules might violate relevant constitutional provisions. ${ }^{14}$ For example, if a state has different systems of marriage law based on the religious denomination of the parties, such a state, in effectuating a constitutional rule guaranteeing the equality of the various religions, must adopt the same criteria for determining the respective scopes of the marriage laws of each denomination..$^{15}$ It could not then apply the marriage law of religion $A$ if either the husband or the wife belongs to it, while applying the ecclesiastical marriage law of the husband's persuasion to all other cases. ${ }^{16} \mathrm{~A}$ rule changing the applicable law in the case of conversion from faith $A$ to faith $B$, but not vice versa, would also be incompatible with a constitutional dictate of religious equality. ${ }^{17}$ Finally, equality of treatment between the various religious denominations within a state requires provision for the applicability of all possible ecclesiastical marriage laws, not only those of certain enumerated denominations. ${ }^{18}$

If the constitution of a country prohibits making private rights and obligations dependent upon religion, not only the discriminatory treatments described above, but all differentiations of private rights based on religion are prohibited. ${ }^{19}$ If the constitution outlaws different treatment according to race or social class, this prohibition also reaches choice-of-law rules delimiting the applicability of different indigenous legal systems in accordance with criteria of race or class. ${ }^{20}$

The discriminatory treatment of the various indigenous legal systems in effect in a pluri-legal state (i.e., a state within which several territorial and/or personal systems of law are simultaneously in force) becomes especially apparent if the interpersonal law of such a state has a general clause aimed against only one of the indigenous legal systems and derogating from otherwise non-discriminatory choiceof-law rules. A well-known example of such a clause is the ordre public colonial

${ }^{14} \mathrm{Sec}$, in this connection, our article, Rechtsgleichheit tund Vielheit der Rechte, in I Ioo JAFrE Deutsches Rechtsleben. Festschrift zuM I00 JüHRigen BesteheN des DeUtscheN JuRistentages 239 ( 1960 ).

${ }^{15}$ Legislation in force in Congress Poland until $189 \mathrm{I}$ gave the Roman Catholic marriage law a preferred position. Until I909, Imperial Russian and Congress Polish law favored the application of the Russian Orthodox law of marriage. See Valladão, Les conséquences de la différence de nationalité des époux sur les effets du mariage et les conditions du divorce, Exposé préliminaire, 44 ANNuArE $\mathrm{DE}$ L'INSTTTUT DE DROIT INTERNational pt. 2, at ro, 32-34 (I952).

${ }^{10}$ Such discriminations in favor of Russian Orthodox marriage law existed in pre-revolutionary Russia.

${ }^{17}$ Sec, e.g., the former section III of the Austrian Civil Code which prohibited the divorce of Protestants who had intermarried as Catholics under Catholic rites and had later converted to Protestantism. Pre-revolutionary Russian law had a similar provision in favor of Russian Orthodox marriage law.

${ }^{28}$ There also would appear to be discrimination if the state leaves those who belong to no religious denomination completely without a marriage law. On such a temporary hiatus for dissenters in Poland, see Wengler, supra note 14 , at 246.

${ }^{10}$ See id. at 253 n.22.

${ }^{20}$ See the decision of the Federal Constitutional Court of May 25, 1956, on article 3 of the Basic Law, [1956] Neue Juristische Wochenschrift 985. See also the decisions of the Supreme Court of the Gold Coast cited by Wengler, supra note $\mathrm{I}_{4}$, at $263 \mathrm{n.4I}$. 
which empowers courts in a colony to disregard native law, but not Européan law. Such a clause would also be unconstitutional in a state whose constitution postulates equality between the various groups of the population and their respective laws. However, it is conceivable that such a discriminatory treatment of the different legal systems effective in a pluri-legal state may be considered to be permissible if one of the various indigenous laws is regarded as the general law, and all the others as special laws. In European countries, for instance, there are differences between the laws of sales contained in the civil codes and in the commercial codes; the applicability of the law of commercial sales, e.g., in Germany, depends on the status of the parties as merchants or non-merchants. The reach of the commercial code is narrower than that of the civil code, because the former regularly depends upon the merchant status of both parties. A state that has a "normal" secular law of marriage and at the same time permits the applicability of the ecclesiastical marriage laws of persons whose religion demands specific rules of marriage law, might also be considered as not discriminating. But the postulate of equality would be violated if those who are not governed by ecclesiastical marriage laws are subjected to a secular marriage law that is based on the principles of one particular denomination or amounts to a mere secular enactment of one particular denomination's rules on marriage. ${ }^{21}$

An unequal delimitation of the scopes of several indigenous legal orders through the use of racial or class criteria, or even the mere use of such criteria, might conceivably violate not only constitutional provisions, but also come into conflict with obligations assumed by treaty. ${ }^{22}$

In a federal state, a discriminatory allocation of the reach of the various territorial legal systems might violate the obligation of the federal lawmaker to accord equal treatment to the organs of local legislation. If the enactment of internal conflictof-law rules is subject to federal regulation, this duty of equal treatment will also imply an obligation to delimit the scope of the various territorial laws on a basis of parity. If the federal legislative power of a state has to be exercised so as to accord equal treatment to the various political subdivisions, this might inhibit enacting different laws of limited territorial application, and obligate the federation to create a uniform law for the entire country. ${ }^{23}$ The prohibition of the unequal treatment of all political subdivisions might also stand in the way of federal legislation that would delimit the scope of the various territorial legal systems by criteria that are typical of only some of them.

Inequality between the various territorial legal systems effective within a plurilegal state can result from the unequal status of the respective legislatures. For

${ }^{21}$ See Wengler, supra note 14 , at 244 n.10; 248 n.I4.

22 The use of religious criteria for choice-of-law purposes or, in any event, the unequal treatment of different religious laws effective within the same state, is hardly compatible with conventions for the protection of minorities or with human rights conventions, where applicable. Id. at 280 et seq. Distinctions in labor law based on eriteria of sex, race, and the like are incompatible with I.L.O. Conventions No. 82 and $\mathrm{III}$, where applicable.

${ }^{23}$ For a discussion of this question as regards Australia and some other states, see Wengler, supra note 14 , at $268 \mathrm{et}$ seq. Similarly, the organs of the European Communities are not permitted to enact regulations that would discriminate against a member state or against part of its territory. 
instance, within the British Empire the Parliament at Westminster could enact so-called extraterritorial statutes, while the legislatures of the various colonies had no such powers. ${ }^{24}$ Such an inequality in the delimitation of the spheres of applicability of the various local laws could be deemed justified if the law effective in the largest subdivision of the pluri-legal state is regarded as "normal," and the different legal orders of the smaller territories are to be preserved only for a limited period of time. ${ }^{25}$

It has been pointed out above that public international law does not prohibit choice-of-law rules that discriminate between the various legal systems by preferring one or more over others. Quite another question is whether such discrimination is incompatible with generally recognized policy principles of private international law. This latter question will have to be answered affirmatively. ${ }^{26}$ In laying down its choice-of-law rules, each state should avoid so far as possible exposing those who are subject to these rules to conflicts of duties resulting from the application of different laws by different states and from the consequent conflicts of adjudication. No real violence is done to this postulate if one state ties status to domicile while others select nationality, or if one state applies the law of the parents' domicile while another applies the child's. But increasing the likelihood of conflicting decisions through choice-of-law rules that treat foreign legal systems on a basis of parity inter se but favor the forum's own law by providing additional grounds for the latter's applicability alone, is incompatible with the postulate that conflicts of duties must be minimized. Discriminatory choice-of-law rules patently enlarge the danger of conflicting decisions in different states, and are for this reason to be rejected de lege ferenda. This conclusion is pertinent not only for interpersonal or interterritorial law, but also for national legislation. ${ }^{27}$

If the postulate of the parity of different national laws is justified not so much by resort to the principle of the sovereign equality of states under international law, but on grounds of individual interest in the avoidance of conflicting obligations, the latter consideration would appear to be pertinent even where the legislative power

\footnotetext{
as The purport of this extraterritorial legislation rule is still rather nebulous. Since the Statute of Westminster, 22 Geo. 5, c. 4 (I93I), it no longer applies to Dominions.

${ }^{25}$ With respect to the parity of the legal orders of a pluri-legal state under its own interterritorial conflicts law, see Wengler, Prinzipienfragen des interzonalen Rechts in Deutschland, [1951] NeUE JuRIstische Wochenschrift 49. In his discussion of the relationship between French law and the local law effective in Alsace-Lorraine, Niboyet speaks of a "préeminence bien naturelle de la loi française vis-à-vis de la loi locale." Jenn-Paulin Niboyet, Conflits entre les lois françaises et les lois zocales D'Alsace-Lorraine I20-3I (I922).

${ }^{30}$ Thus, the Resolution of the Institut de Droit international of April 25, 1952, provides expressly: "The rules of private international law should not... make use of connecting factors (points de rattachement) which give rise to a difference between the spheres of application of national and foreign legislation." Loc. cit. supra note $\mathrm{r} 3$.

${ }^{37}$ A treaty could, of course, provide that all contracting states have to accord a greater scope to the law of one of the parties than to the laws of the other states; but such a provision will hardly be found in treaties for the unification of rules of private international law. Some conventions permit the signatory states to extend the scope of their respective leges fori unilaterally, without, however, requiring that they do so; see, e.g., article 2, section 2 of the Convention for the Settlement of Certain Conflicts of Laws in connection with Bills of Exchange and Promissory Notes, of June 7, I930, 143 L.N.T.S. $317,325$.
} 
that is actually exercised in a given territory is internationally illegal in origin (e.g., legislation of an aggressor state for territory incorporated in violation of international law). Nevertheless, there may be other basic principles of private international law that might justify a refusal by third states to apply the law enacted by the illegal occupant. Still, such third states will not generally be able to ignore the fact that the inhabitants of the occupied territory cannot escape obeying the occupant's decrees. It therefore seems appropriate on general, humanitarian grounds, to give preference to the effective but illegitimate law over the law of the rightful sovereign. ${ }^{28}$

A state that strictly observes the postulate of the equal treatment of the various substantive legal orders in its own private international law might possibly defend itself against discriminatory foreign choice-of-law rules. For instance, it might, through retaliatory clauses, extend the applicability of the lex fori as against the laws of those states that do not observe parity in choice of law. But the consequence of such reprisal clauses will usually be that "innocent parties" are exposed to conflicting decisions in different states.

If the forum's choice-of-law rules generally refer to the whole foreign law, it is conceivable that there will be no renvoi as to discriminatory foreign choice-of-law rules. Let us assume that under Argentinian private international law, the Argentinian law of succession is applicable not only if the decedent was domiciled in Argentina, but also to parts of the estate situated in Argentina irrespective of domicile, while there is no parallel clause with respect to goods situated elsewhere. ${ }^{20}$ If German private international law is generally willing to follow Argentinian choice-of-law rules when the German choice-of-law rule refers to Argentinian law, a German judge might conceivably transform the unilateral Argentinian rule into a multilateral one. He would thus apply German law to those parts of the estate of a decedent last domiciled in Argentina that are permanently situated in Germany, while the Argentinian judge would apply Argentinian law with respect to those goods as well. The public policy of the forum might thus prevent the application of discriminatory foreign choice-of-law rules.

A discriminatory treatment of foreign law as regards proof, appealability, or the competence to apply certain rules, would not as such be violative of the postulate of allocation of the spheres of applicability of all legal orders on the basis of equality. This is not the place to discuss the minutiae of international civil procedure; and it will suffice to point out that inequality of treatment will probably follow if courts that are competent to decide a particular type of controversy are completely without power to apply anything but the lex fori. Not all such cases where the courts are limited to the application of their own law will, however, be productive of inequality.

\footnotetext{
${ }^{28}$ See Wengler, Fragen der Faktizität und Legitimität bei der Anwendung fremden Rechts, Festschrift Hans Lewald 615, 627 et seq. (1953).

${ }^{20} \mathrm{See}$, in this connection, Wengler, supra note $\mathrm{I}_{4}$, at n.125.-Another example that seems relevant in this connection is the practice of some Anglo-American jurisdictions to permit the forum's own executors and administrators to act in other states, but to require ancillary probate proceedings before a foreign personal representative can act in the forum state.
} 
If the courts of a state can apply only the lex fori to divorce actions subject to their jurisdiction, the equal treatment of the divorce laws of other states requires the recognition of at least all foreign divorce decrees rendered under like circumstances. Inequality will also result if courts are empowered to apply foreign substantive law by virtue of nondiscriminatory choice-of-law rules, but have jurisdiction for such purposes only if the relevant foreign law is totally or at least substantially identical with the lex fori ${ }^{30}$

Let us concede that the procedural treatment of foreign law works in favor of the lex fori even if the choice-of-law rules are nondiscriminatory, and that the application of such nondiscriminatory rules will in most instances lead to the application of the lex fori, anyway. In our judgment, this does not mean that the policy justification for the equal treatment of the various systems of substantive law has, as a practical matter, become so devoid of significance that the postulate of equality itself has become meaningless. (This latter view seems to have found adherents especially in the United States.) ${ }^{31}$ At least in Western Europe, increased international trade and migration have led to an increase in the proportion of those cases that cannot be decided in accordance with the lex fori; and here, it is increasingly recognized that the individual should not unnecessarily be subjected to conflicting obligations by discriminatory choice-of-law rules.

Even the thought that the equal treatment of foreign laws inter se is not necessary, may find adherents in this era of cold war. If in a Western country, the question arises whether the law of an Eastern or of a Western state should govern (the lex fori not being applicable), some may consciously or subconsciously prefer the application of "Western" law. Equal treatment of "Eastern" and "Western" law will appear to be particularly inappropriate where, as is the case with respect to Germany, an originally unified state has been divided into two parts which are in a state of cold civil war with each other. But this is a pathological disturbance that should not be drawn upon to justify the discriminatory treatment of different legal orders where such legal orders have grown on the same ideological foundations and are different only because of historical and other accidents. If these national legal cultures are to respect each other's individuality and, thereby, their differences, the equal treatment of their laws by the relevant choice-of-law rules appears to be a necessity that is inescapable.

\section{II}

\section{The Equal Treatment of the Parties in the CONFLICT OF LAws}

If the judge of the forum state has to apply domestic law to some cases and foreign law to others, and if the laws that are made applicable by the forum's

${ }^{30}$ Especially in Germany, this practice is sought to be justified in part by the argument that the relevant procedural law is tailored to fit substantive rules of a specific content.

${ }^{31}$ See especially the studies of Brainerd Currie, e.g., Currie, Notes on Methods and Objectives in the Conflict of Laws, 1959 Duke L.J. I7I. Currie's theories are reminiscent of those advanced by Carl Georg von Wächter more than a hundred years ago. Wächter, Über die Collision der Privatrechtsgesetze (4 pts.), 24 ARchiv für die crvilistische Praxis 230 (I84I); 25 id. I, I6I \& 36I (I842). 
choice-of-law rules do not happen to be identical, it necessarily follows that parties subjected to the law of State $A$ because of the presence of connecting factor $X$ are treated in a different manner from persons whose corresponding legal relationships are subjected to the law of State $B$. It has often been pointed out in judicial decisions that the unequal treatment of parties in the forum state that results from the application of foreign laws to some cases and of domestic law to others, is not violative of the constitutional rule of the equality of rights. For the treatment of all persons within a state on the basis of absolute equality would necessitate the application of the lex fori to all cases, without regard to any contacts to foreign legal systems that might be present. ${ }^{32}$ But so long as every state governs only part of the world, and so long as the coexistence of several states with different legal systems is regarded as legitimate, manifestly the appropriate solution is the application of different substantive laws by courts of the forum state, selected according to the contacts of each individual case to the legal order of this or that state. Still, at this point we reserve discussion of the question whether the principle of equality might not require the rejection, through resort to the public policy exception, of those rules of law that are too radically different from the lex fori. ${ }^{33}$

Once it is conceded that the selection of different laws by pertinent choice-of-law rules in accordance with appropriate criteria is not arbitrary unequal treatment, it follows that there is no arbitrary discrimination if within a forum state that has chosen criterion $X$ for a certain relationship, parties that share quality $Y$ are subjected to different substantive laws. If a German judge (should he have jurisdiction over questions involving foreign real estate) will apply the lex rei sitae and thus, e.g., French and Swiss law to the rights of some German nationals in real property and German law to others, this will not earnestly be contended to be violative of the equal rights clause of the Basic Law. Consequently, no real inequality of treatment exists where the forum state has chosen as the connecting factor a criterion related to the status of only one of the parties to a legal relationship, so that the other parties to the same relationship are subjected sometimes to this law, and sometimes to that.

Let us illustrate: Austrian law at least in principle applies the national law of the adoptive parent to international adoptions, but probably takes account of renvoi of the national law to Austrian law. Now suppose that citizens of the United States resident in Michigan desire to adopt a child residing in Austria, and request the confirmation of the adoption agreement by an Austrian court. The court ${ }^{34}$ will have to determine which law is applicable under Michigan choice-of-law rules. If, as asserted, Michigan referred back to the law of the child's domicile, the question of the age requirement would have to be decided in accordance with Austrian sub-

\footnotetext{
s2 In its decision of March 13, 1956, [1956] Bayrisches Gesetz- UNd Verordnuncsblatt 78, the Bavarian Constitutional Court held that the principle of equality would not support the assertion that "only German law may be applied to all legal relationships to be adjudicated in Germany."

${ }^{83}$ See infra p. 854 et seq.

"See the decision of the Supreme Court of Austria of January 21, 1959, I3 Oesterreichiscires StaNDESAMT 57 (I959).
} 
stantive law. But, it was objected, this solution could not possibly be correct, because it seemed inconceivable that Michigan would do such violence to the equality principle as to let a multitude of different foreign laws decide whether a non-resident child can be adopted by Michigan domiciliaries. Our interest in this case is not whether renvoi is part of Austrian private international law, nor whether Michigan actually does refer back to the child's domicile. We are merely concerned with the claim of unequal treatment: it is asserted that a choice of the lex adoptionis based on the domicile of the adopted constitutes an unwarranted discrimination between prospective adoptive parents who are all domiciled within the same state. By the same token, it could obviously be claimed that, should the lex adoptionis be the law of the adoptive parents' domicile, this would be an unwarranted discrimination between all children domiciled within one state.

Obviously, the dilemma is not avoided by a choice-of-law rule that cumulates both leges domicilii and recognizes only those adoptions that are valid under the law of both the adoptive parents' and the child's domicile. This would discriminate not only against those prospective adoptive parents who cannot adopt because of the child's personal law, but also against those children who cannot be adopted because of the prospective adoptive parents' personal law. The complaint of discrimination will also not be silenced by a rule choosing the law that favors adoptions, i.e., permitting adoptions if they are permissible under the personal law of either the child or the adoptive parents. In this case, there still will be discrimination inter se both between all children domiciled within the same state, and between all prospective adoptive parents domiciled within the same state.

If a nondiscriminatory choice-of-law rule, i.e., a rule that accords the law of every state an equal chance of application, chooses the law governing a particular relationship by means of criteria based on the status of one of the parties typically involved in such a relationship, but not that of other parties also typically involved therein, the application of different laws to members of the latter group is unavoidable. But this seeming inequality is discriminatory only if the connecting factor is such that the party whose status is decisive can, through a change of the relevant criterion, manipulate the applicable law to the disadvantage of the other party. If, for instance, the proper law of divorce should be that of the husband's and not the wife's nationality, this alone does not put the wife at a disadvantage, for conceivably the husband's national law is more favorable to the wife than her own. Still, the selection of the national law of the husband as the law governing divorce discriminates against the wife because the husband by unilateral decision can change his nationality and thus acquire a national law that favors him. ${ }^{35}$ Only if a change of the husband's nationality could not take place without the wife's consent would there be no possible discrimination against the wife in the selection of the national law of the husband.

\footnotetext{
${ }^{35}$ This is overlooked in the decision of the Federal Supreme Court of January I8, I954, [1954] NeUe JuRIstische WocheNschrift 837. The Court is of the opinion that article I7, section I EGBGB is not incompatible with the constitutional prohibition of discrimination on grounds of sex.
} 
Other instances of objectionable derogations from the principle of equality through discrimination between the parties occur particularly where the applicable law depends upon the will of one of the parties, but not the other. We have already mentioned the cases in which there is a disproportionate increase in the scope of the lex fori because certain specific groups of persons-especially nationals of the forum state in their dealings with aliens-can demand the application of the lex for $i$ instead of the law that normally governs. In this type of situation, there is not only a discrimination between the various legal systems inter se, but also a discrimination between the parties in the shaping of the choice-of-law rule. Wherever a party may request the application of this or the other legal system, it can be expected that such choice is made in terms of anticipated advantage. (Of course, the choice of the law that is more favorable to a party could conceivably also be left to judicial determination.)

There can be many variations of this favoring one of the parties by the choiceof-law rule itself. The determining factor may be a specific permanent characteristic of one of the parties in litigation that has nothing to do with the litigation as such; e.g., a choice-of-law rule that selects that one among several potentially relevant laws which favors a party who is a national of the forum state-assuming, of course, that the other party is an alien. ${ }^{36}$ There can also be a rule that favors selecting the law favorable to the defendant as against the plaintiff, the wife as against the husband, the child as against the parents, or the employee as against the employer. ${ }^{37}$ The favoring of one of the parties can also be hidden underneath a rule providing for the application of that law which leads to a certain result, e.g., the upholding of a contract or of a will, or the granting of a divorce decree; for here, invariably the party having an interest in that particular outcome is favored over the other party. Thus, most choice-of-law rules that provide for the cumulative or the alternative application of the laws of several states in reality favor one party over the other. But while weighing the interests of the parties is a vital legislative function in the enactment of substantive law, this consideration should, at least according to the better view, not be relevant in shaping choice-of-law rules.

The preferential treatment of one of the parties in litigation by means of a choice-of-law rule may also be violative of international law if it amounts to a discrimination in favor of the forum's own nationals in derogation of treaty obligations. If we assume that the national treatment clauses of establishment conventions also apply to private law rights of nationals of the contracting states, ${ }^{38}$ such states

${ }^{36}$ See supra p. 823 .

${ }^{37}$ Even article 3 of the Hague Convention on the Law Applieable to Obligations to support Minor Children, of October 24, 1956, 5 AMr. J. Comp. L. 656 (1956), provides that "Contrary to the preceding provisions [i.e., the uniform choice-of-law rules established by this treaty, Ed.], the law designated by the national conflicts rules of the authority concerned is applicable, in case the law of the habitual residence of the minor child [the law governing by virtue of article x, Ed.] denies him any right of support."

${ }^{38}$ This would seem to be the case with respect to the European Convention on Establishment, of December 13, 1955, European Treaty Series No. I9 (article 4).

The national treatment clause in establishment conventions is paralleled by the privileges and im. munities clauses frequently found in federal constitutions, which prohibit discrimination by political 
may also not make the applicability of one out of two or more potentially relevant laws contingent upon the criterion of advantage to their own nationals. ${ }^{39}$

An example of such internationally objectionable choice-of-law rules is the German conflicts rule regarding torts: the torts committed by Germans abroad are governed by the lex loci or by German law, whichever is most advantageous to the German defendant, ${ }^{40}$ while torts committed by aliens outside of Germany are subject solely to the lex loci. There also is discrimination against aliens ${ }^{41}$ by choice-of-law rules if heirs who are nationals of the forum state can select the lex fori instead of the national law of the decedent, while the rights of alien heirs are governed exclusively by the decedent's national law. Such a provision, too, in our opinion violates the national treatment clauses of international conventions. ${ }^{42}$

Another provision of doubtful legality in the light of treaty obligations to accord national treatment is article 7, section 3 of the Introductory Law to the German Civil Code which provides that the capacity of aliens as regards transactions in Germany is governed by their national law or by the German lex fori, whichever favors the validity of the transaction. This provision is discriminatory because under German private international law the capacity of German nationals is regulated exclusively by German substantive law, irrespective of the place of the transaction. But how could equality between Germans and aliens be guaranteed in this area? If it should be provided that German law governs capacity with respect to all transactions in Germany by aliens, discrimination could be avoided by providing that the capacity of Germans acting abroad is governed by the lex loci actus at least where the other parties are not Germans. Or does it follow from the national treatment clause that the capacity of aliens acting in Germany is to be regulated solely by their national laws? In any event, there seems to be more than one possible way of

subdivisions against the subjects of other political subdivisions; see, e.g., article 3 of the German Constitution of $187 \mathrm{I}$. With respect to the significance of the constitutional prohibition of discrimination against the citizens of other states in United States interstate conflict of laws, see Hill, Governmental Interest and the Conflict of Laws-A Reply to Professor Currie, 27 U. CHI. L. Rev. 463, 479 et seq. (1960); Currie \& Schreter, Unconstitutional Discrimination in the Choice of Law: Privileges and Immunities, 69 YALE L.J. I323 (I960).

${ }^{80}$ The discriminatory treatment of aliens by private law rules, including choice-of-law rules, can also conflict with a constitutional standard of equality, see GüNther Bertzke, GRuNdGesetz und INTERNATIONALPRIVATRECHT 22-23 (I96I); but see Makarov, Note, 50 REVUE CRITIQUE DE DROIT INTERNATIONAL PRIVE 732, 734-36 (I96I).

${ }^{10}$ See article 12 EGBGB.

11 Of course, it is also possible that a choice-of-law rule actually discriminates against nationals of the forum state. For example, the legitimacy of children born to a German mother can be challenged both under the mother's national law and under that of the husband, while the legitimacy of children born to alien mothers is, under German private international law, solely governed by the national law of the husband. Article I 8 EGBGB.

"However, it has been assumed in France that the "droit de prélèvement" of French heirs is not superseded by national treatment clauses in establishment conventions, see 4 MARcel PLANiol \& Georges RIPert, TRAité PRatique de DRoIt civil français 69-70 (I928). The reason given is that this right can also be asserted by a Frenchman to the detriment of another Frenchman who would take if foreign law governed the succession. Thus, it is argued, the droit de prélèvement is no specific discrimination against aliens in favor of French nationals. There appear to be no reported French cases on the question whether aliens entitled to national treatment in France by virtue of a treaty can demand a droit de prélèvement under French law, or, conceivably, their own national law. 
bringing present German private international law into harmony with international obligations to accord national treatment. ${ }^{43}$

Another example of the discriminatory treatment of one of the parties (the party that is an alien) is provided by article 17 of the Introductory Law of the German Civil Code, which deals with the substantive law applicable to divorce actions in German courts. Under this provision, an alien husband married to a German wife can obtain a divorce only if it is available both under his national law and under German law. On the other hand, if the German wife is seeking a divorce from her alien husband, only German law is applicable. If both parties are aliens, divorces can be granted by German courts only if there are grounds for divorce both under the German lex fori and the husband's national law. In any event, the alien husband's chances of obtaining a divorce from his German wife are smaller than the wife's opportunity to divorce her alien husband, because there is a cumulation of the national law and the lex fori in the former but not in the latter case.

A standard type national treatment clause does not stand in the way of choice-oflaw rules that favor persons connected to the forum state by factors other than nationality, e.g., domicile or permanent business establishment. The national treatment clause also will not bar conferring upon persons singled out by such criteria the power to choose the applicable law on grounds of personal advantage. But the most modern treaties already have provisions condemning such "national discriminations." These provisions do not prevent the contracting states from segregating discrete types of legal relationships into separate categories and subjecting each of these to a different national law. They do, however, outlaw choice-of-law rules that favor parties connected by whatever criterion to the forum state through enabling them to choose to their own advantage between two or more potentially applicable substantive laws. Thus, a general prohibition of "national discrimination" in a treaty ${ }^{\mathbf{4 4}}$ does not bar the unequal delimitation of the various national legal systems by the choice-of-law rules of a contracting state; but it does prohibit an extension of the scope of the lex fori through the use of the criterion of concrete advantage to a party connected in some manner with the forum state.

It has been pointed out above that the principle of equality is not violated by the mere existence of several legal systems in a pluri-legal state, but that it is offended if the delimitation of the scopes of the various territorial orders is made dependent upon the membership of a person in one of the territorial communities. It seems possible that the national treatment clause of a treaty might likewise preclude choice of law based on nationality, while the use of criteria such as domicile or situs remains

${ }^{38}$ A provision substantially identical with article 7 , section ${ }_{3}$ EGBGB was to be found in the former Civil Code of Saxony (article 8). In a decision of December r8, 1869, the Court of Appeals of Dresden held that this latter provision was incompatible with the privileges and immunities clause of the Constitution of the North German Federation. 24 Seufferts Archiv No. 186.

"Article 4 of the European Coal and Steel Community treaty is presently understood to cover all forms of national discriminations. Article 7 of the European Economic Community treaty prohibits primarily only the discriminatory treatment of purchasers on the basis of their respective nationalities; other provisions cover certain other forms of national discriminations, e.g., those based on the origin of products (article 33 ). 
permissible. So far as can be determined, however, such consequences have not followed up to the present from standard ${ }^{45}$ national treatment clauses. ${ }^{46}$

Even where discrimination in favor of one of the parties to a legal transaction does not run afoul of national treatment clauses, it is still possible that states react to such discriminatory choice-of-law rules of other states by themselves enacting discriminatory choice-of-law rules applicable only in relation to states which so discriminate. However, such retaliatory provisions will in most cases work to the disadvantage of "innocent" parties.

\section{III}

\section{The Equal Treatament of Similar Social Relationships in The Conflict of Laws}

\section{A. Different Methods for Teaching Multiple Contact Cases-Equal Treatment of Multiple and Single Contact Cases}

The following may elucidate our thoughts in this chapter: We distinguish between legal relationships-or better, situations-that are connected only with one state (or more accurately, with only one territory with a uniform system of private law), and situations that have contacts of the kind generally used for choice-of-law purposes with several states. As regards the homogeneously connected situations (single contact cases), they are obviously governed only by the law of the state with which they are connected. Heterogeneously connected situations (multiple contact cases), on the other hand, could arguably be dealt with in no less than four different ways. First, they could be subjected to one of the legal orders with which

45 Treaties that expressly provide that the personal status of nationals of the contracting states shall be governed by their respective national laws, sometimes indicate that such provisions are in derogation of the national treatment standard. See, e.g., sections I \& 2 of article 6 of the Consular Convention of October 6, 1948, between Greece and the Lebanon, 87 U.N.T.S. 35I, 357:

"Nationals of either High Contracting Party shall be subject, in the territory of the other Party, under the same conditions as its nationals, to the territorial legislation, the general principles of international law, and the criminal, civil, commercial, administrative, fiscal or other laws, decrees, orders and regulations. So far as their personal status is concerned they shall however remain subject to the provisions of their national law." (Emphasis added.)

If the constitution of a federation obligates the member states to treat citizens of other member states on the basis of equality with their own citizens (see supra note 38 ), it might be that member states may not select state citizenship at all as a criterion for the interstate choice of law, while the criterion of domicile would be acceptable. Article 12 of the United Nations Convention of July 28, r951, Relating to the Status of Refugees, I89 U.N.T.S. 150, subjects the personal status of refugees to the law of their domicile. This refers to whatever law the domiciliary state applies to its nationals domiciled in the same locale as persons entitled to the benefits of the Convention.

The European Coal and Steel Community treaty prohibition of national discrimination in commercial transactions concerning coal and steel would also bar sellers of these products from adopting general sales policies that differ according to the nationality of the buyers.

${ }^{10}$ It is conceivable that a treaty obligates two states to treat their nationals equally but that so long as these two states do not agree upon a uniform system of law, one of them cannot realize such a program. See, in this connection, the decision of the Court of Appeals of Nouméa (New Caledonia) of July 12, 1960, [ig6i] Recueil Pennnt (Revue du droit des pays d'Afrique) 248: The Anglo-French Protocol of October 20, 1906, guarantees equal protection of the law to French and British subjects in the Condominium of the New Hebrides, but this does not prevent the French authorities, which have legislative jurisdiction only with respect to French subjects, from enacting labor safety regulations applicable to French employers only, despite the fact that parallel regulations have not been enacted by the appropriate British authorities. 
they are connected, selected by the use of one of their contacts. ${ }^{47}$ Secondly, they could be considered in the light of several or all potentially relevant legal orders, and one of these could be ultimately selected after such comparative analysis; for the latter purpose, there would have to be a criterion of preference. Thirdly, it seems possible to maintain that no legal system that governs single contact cases will be adequate for the solution of multiple contact cases, and that consequently a special substantive law has to be created for the latter by the legislature (or, if need be, by the courts). Fourthly and finally, it could be contended that situations not connected to only one country and to its law in every respect must remain free from all legal regulation. ${ }^{48}$

It is not difficult to see that only the first method will lead to formal equality of treatment between single and multiple contact cases. For it seems that if single contact cases are subjected to only one legal system, equal treatment of multiple contact cases will require that they, too, be governed by only one law; and all that is needed is some rule that selects one of their multiple contacts for the determination of the proper law.

On the other hand, the fourth of the above alternatives, which completely denies the possibility of the legal regulation of multiple contact cases, is farthest apart from the postulate of equality in the treatment of single and multiple contact cases. Where this solution is adopted, there could, for instance, only be valid marriage if the prospective spouses are both domiciliaries and nationals of the same country, and if the marriage is celebrated there; all other "marriages" with even one heterogeneous connecting factor would be mere "concubinage." This kind of situation can indeed exist if one state reserves the rights created by certain rules of its private law system to its own nationals, judging such rights to be so-called droit civils, and if other states do likewise. For instance, a state that regards rights flowing from an adoption pursuant to the lex fori to be such droits civils, might recognize adoptions as between aliens in accordance with their joint national laws. It might possibly also enact choice-of-law rules to select the law governing adoptions involving aliens of different nationalities if the foreign states concerned do not also regard the creation

\footnotetext{
17 Another variant of this first method is "splitting up" the legal relationship at hand and subjecting each of its component parts to one legal system, respectively; see infra at p. 844 .

"Interestingly enough, so-called "mixed" or "atypical" contracts, i.e., contracts that do not fit into one of the standard categories provided for by law, can also be dealt with in the same four alternative ways. Some would subject the entire atypical contract to the law governing that standard type of contract which is most similar to it (method of absorption). Others seek to apply rules for several standard type contracts in combination. Here, it is possible to subject certain aspects of the atypical contract to the rules governing standard contract $A$, and other aspects of the same atypical contract to rules governing standard contract $B$. Conceivably, the rules governing different types of contracts could also be applied alternatively or cumulatively. Still other authors would apply only those rules that are common to all standard type contracts. There also is some tendency towards the creation of a special legal régime for atypical contracts that is merely inspired, but not governcd, by the rules applicable to standard contract types. A parallel to the fourth of the alternative methods sketched above would be a rule that outlaws atypical contracts entirely. Surprisingly, commentators on private international law have thus far failed to observe that the quest for rules to govern atypical contracts raises problems of the same structure as those encountered in the search for a proper law of multiple contact cases.
} 
of the status of adoption under their respective laws as a droit civil. In any event, however, such a state will refuse to grant adoptions as between aliens and its own nationals under the lex fori; and it will probably also refuse to lend its administrative or judicial machinery to grant adoptions as between aliens. Since here, the unequal treatment of single and multiple contact cases is coupled with discrimination between nationals and aliens, this might run afoul of treaty obligations to accord national treatment. ${ }^{49}$

B. Inequality Through the Application of Several Laws to Multiple Contact Cases?

The second and the third of the above-mentioned methods for the "solution" of multiple contact cases have ingredients that make it plausible to assume that the use of these methods will not be discriminatory as judged by the treatment of single contact cases. An initial reaction might well be that subjecting a multiple contact case not to one law but to several laws is quite appropriate. But the simultaneous application of several laws to the same situation is only possible if these laws do not contradict each other. Let us illustrate: Suppose $X$ and $Y$ both suffered injury through an allegedly tortious action, and the case has contacts with two states, $A$ and $B$. Now, if State $A$ grants a claim for damages to $X$ but not $Y$, and if conversely, State $B$ grants a claim to $Y$ but not to $X$, it seems possible to apply the law of both states at the same time. If claims of $X$ against $Y$ or of $Y$ against $X$ are in issue, and if each party could recover under the law of either $A$ or $B$, the result-possibly a setoff of $X$ 's and Y's claims against each other-would hardly be considered to be sensible. Suppose, further, that an inheritance dispute has connections with States $A$ and $B$, and that $X$ takes everything under the law of $A$, while $Y$ takes everything under the law of $B$. Here, the cumulative application of the laws of $A$ and $B$ to the same case is impossible.

On the other hand, wherever several laws are taken into consideration but where, in order to avoid inconsistencies, only one of them is ultimately applied, ${ }^{\mathbf{5 0}}$ there necessarily has to be a criterion for preferring one law over the others. Even where this criterion is not a personal attribute of one of the parties but an attribute of the outcome of the application of the law chosen, there will be discrimination between single and multiple contact cases. If a choice-of-law rule does not subject a multiplecontact contract solely to the law of $A$ but provides that its validity shall be de-

${ }^{\circ}$ A state that regards the creation of certain legal relationships as droits civils of its own nationals, will be obligated by national treatment clauses in establishment conventions either to permit the creation of such legal relationships under the lex fori by treaty aliens, or to permit the creation of such relationships in the forum state in accordance with foreign law. At a time when adoption was still regarded as a droit civil reserved to Frenchmen while establishment conventions to which France was a party contained national treatment clauses, France preferred the former solution. This, in turn, inured to the benefits of aliens entitled to most favored nation treatment, see the decision of the Tribunal Civil de la Seine of March 13, 1889, [1889] Journal du droit international (Crunet) 803.

"In this connection, "alternative" application of several laws refers to a process ultimately leading to the application of that law which favors the creation, or the extension, of the obligations of one party (and of corresponding rights of another party). "Cumulative" application of several laws, on the other hand, leads to the choice of that law which imposes the least obligations and creates the least rights. 
termined in accordance with the laws of $A, B$, and $C$, this rule must also provide either that a contract is valid under the lex for $i$ if enforceable under either of these laws, or that it is enforceable only if valid under all of them. In any event, conflicts law here has to take a stand on an issue of substantive law: whether or not the validity of contracts is to be favored. Whatever position is adopted on this issue, there will be different standards for single-contact and for multiple-contact contracts. ${ }^{\text {Wt }}$ To express it in mathematical categories: if the probability of the validity of a contract solely connected with the law of $A$, and solely subject thereto, is $x$, and the same probability as regards a contract solely connected with State $B$ is $y$, then the corresponding probability for a multiple-contact contract connected with both $A$ and $B$ is $x+y$ if the rule is that the contract will be upheld if valid under any law with which it has contacts. As Professor Quadri has aptly observed, single-contact transactions are discriminated against where multiple-contact transactions are upheld if valid under one of several different laws. ${ }^{52}$ Such a choice-of-law rule, ${ }^{53}$ he has rightly pointed out, implies the application of unequal standards.

On the other hand, it might be asked whether the alternative application of

${ }^{82}$ The principle of equality has also been discussed in connection with the problem of shaping a law to govern atypical contracts, mentioned supra note 48 . As was rightly pointed out by Professor Gény, the law to be applied to atypical contracts has to be selected in such a manner as to prevent their being free from any mandatory rules that govern standard type contracts. 3 Françors GÉnY, Science ET TECHNIQUE EN DROIT PRIVÉ POSITIF I 40 et seq. (I92I).

${ }^{52}$ Quadri, Sulla legge applicabile alla "forma" dei negozi giuridici, 2 SCRITTI dI DIRITTO INTERNazIONALE IN ONORE di Tomaso Perassi 233, 239 (I957).

${ }^{83}$ Some authors apparently fail to see that there is inequality here. Professor Kegel, for instance, has no objections against determining the mutual obligations of the spouses in a "mixed" marriage (i.c., a marriage between spouses of different nationality) in accordance with the "weaker" law, i.e., that law which imposes the least obligations. Gerhard Kegel, Internstionales Privstrecht 237 \& 254 (1960). This method overlooks that some legal systems compensate for the lack of some obligations between spouses by imposing other obligations. But above all, it ignores that the principle of the "weaker" law generally leads to less stringent system of matrimonial law for "mixed" marriages than for marriages between spouses of the same nationality. German courts therefore rightly seek to arrive at the application of one law to such cases by reference to the former common nationality of the spouses, or to their former common domicile; see article 14, section 2 EGBGB and the decision of the Amtsgericht (county court) Berlin-Zehlendorf of March 15, 196r, [1961] NEUE JURIstische WOCHENSCHRIFT I 728 .

Schwind, Von der Zersplitterung des Privatrechts durch das Internationale Privatrecht und ihrer Bekämpfung, 23 RABels Zeitschrift für ausLändisches und internationales PRIvatrecht 449, 457-58 (1958), rejects Kegel's principle of the "weaker" law. His remarks, in turn, are cited with approval by Bydlinski in his report on the principle of equality in Austrian private law, I VenHANDLuNgen DEs öSTERREICHISCHEN JURISTENTAGES I59 (I96I) in connection with his discussion of ways of safeguarding the equality of men and women in private international law. Although Bydlinski deals with the general subject of the principle of equality in private law, he somewhat surprisingly fails to observe that the application of the "weaker" law to multiple contact cases involves their unequal treatment as compared to single contact cases.

In the United States, it is urged, without hesitation, that if a contract has contacts with several states, the law favoring the validity of the transaction should be applied. Professors Cheatham and Reese consider this appropriate, in any event, if the forum states has a general policy in favor of the validity of transactions. Cheatham \& Reese, Choice of the Applicable Law, 52 Colum. L. REv. 959, $978 \mathrm{et}$ seq. (1952). But if a contract is invalid even under the liberal rules of the forum state, with which it has some contacts, it is difficult to see why the public policy of such a state should dictate that the contract, in order to be upheld, be subjected to the law of another state with which it also has some contacts. If the contract has contacts only with other states but not with the forum, there appears no reason why the policy of the lex fori to favor the validity of transactions should have any influence on the choice of the proper law. 
several legal systems for the validation of multiple-contact transactions is not a form of compensation for the enhanced uncertainty of the parties as to the law applicable in multiple contact cases. There surely would be discrimination against multiplecontact transactions if they were treated as enforceable only if valid both under the lex loci actus and the lex causae, i.e., if several laws were not applied alternatively but cumulatively. ${ }^{54}$

Just as alternative validation as to form favors multiple contact cases, so it is with party autonomy as to substantive contracts law not otherwise subject to the disposition of the parties. The opportunities of the parties to choose a convenient law, i.e., one that favors the validity of their undertakings, will increase in proportion to the number of states with which the transaction has contacts. Such a preferential treatment of multiple-contact contracts could, however, be regarded as justifiable if the parties to such contacts are at the same time treated in other respects less favorably than parties to single-contact contracts. This would especially be the case if the forum, while permitting the choice of one unwaivable contracts law from among several possible laws, nevertheless applies the regulatory laws of all states not chosen by the parties, provided that these latter states want their laws to be applied and that they have particularly intensive contacts with the case. ${ }^{55}$

There may also be rules that discriminate between different types of multiple contact cases. For instance, a choice-of-law rule for the determination of the formal validity of contracts for the sale of movables concluded in one state and to be performed in another may provide that they are enforceable if valid under either the lex loci actus or the lex solutionis, but that the validity of like contracts for the sale of immovables is governed exclusively by the lex rei sitae. ${ }^{56}$ Or there could be a rule that permits alternative validation of multiple-contact transactions under the lex loci actus and the lex causae only if all parties to the transaction are not domiciled within the state of contracting, but applies the latter's form requirements exclusively if all parties are domiciled there. ${ }^{57}$

Thus, the cumulative or alternative application of several laws to multiple contact cases appears to be discriminatory in some way (not necessarily unfavorable) when compared to the treatment of single contact cases or multiple contact cases that are automatically subjected to only one law. Such a discriminatory treatment of substantively similar legal relationships in the conflict of laws by the cumulative or alternative application of several laws to multiple contact cases can, as has been shown above, be coupled with a similarly discriminatory preference in favor of the lex fori; it can also be coupled with the discriminatory treatment of aliens. The latter is the

si In this case, the probability of the validity of a multiple-contact contract would be $x-y \%$.

Es See infra p. 857-58.

${ }^{80}$ See article II EGBGB.

${ }^{47}$ See also article 3, section 3 of the Convention for the Settlement of Certain Conflicts of Laws in connection with Bills of Exchange and Promissory Notes, of June 7, 1930, I43 L.N.T.S. 317, 325: As between nationals of the forum state, a bill or note that is invalid under the lex loci actus can be upheld if valid under the lex fori. But there is no parallel provision authorizing the forum state to apply its own law in order to uphold the validity of negotiable instruments made by aliens abroad. 
case, for instance, if the validity of a gift is generally governed by the national law of the donor but if gifts that are invalid under that law are nevertheless enforced when the donee is a national of the forum state and the gift is valid under the lex fori. ${ }^{58}$

It follows that the predominant technique of private international law that proceeds directly to the choice of the law of one state without a preliminary inquiry into the hypothetical result of the application of several arguably relevant laws, is ultimately justified, in principle, by the consideration that this method seems to come closest to the realization of the goal of equal treatment for substantively similar single and multiple contact cases. Nevertheless, it would probably be wrong to assume that multiple contact cases must invariably be subjected to only one law, and that equality requires the complete elimination of all rules for the cumulative or alternative application of several laws. Torts cases would seem to deserve special mention at this point. The choice-of-law rules of most states provide for the cumulative application of the laws of all states that can be regarded as the locus delicti because the tortious conduct either occurred or took effect within their borders. It is significant that almost all other choice-of-law rules do not provide for a similar cumulation whenever the special fact situation at hand points to more than one law, but that almost invariably, the choice-of-law rule is further refined to provide for the application of only one law. For instance, if "nationality" is the criterion and if a party is a dual or multiple national, the generally recognized rule is that the effective -or better, the relatively more effective-nationality alone is considered. If, for example, the capacity to marry is at issue and a prospective spouse is a plural national, there will be no alternative or cumulative application of his or her various national laws. ${ }^{59}$ If a different rule is followed with respect to torts-i.e., if the plaintiff is permitted to choose the law more favorable to him where conduct and effect occurred in different states-this obviously means that the defendant in a multiple-contact tort is more likely to be held liable than are defendants in single-contact torts. Nevertheless, this is not a discriminatory treatment of multiple-contact torts. Torts claims are uniformly based on laws enacted in the public interest and restraining the freedom of individuals. Especially where violations of these laws are also subject to penal sanctions, private international law can assume that laws governing multiplecontact tortious conduct can be enacted by several states. Public international law permits the imposition of penal sanctions not only by the state where the act or omission occurs, but according to predominant opinion also by the state where such conduct produces effects, and possibly also by the state of the offender's or of the victim's nationality. Every person whose activities are not restricted to his own state therefore takes the risk that public law rules of several states seek to affect his

${ }^{58}$ See supra at note 6.

${ }^{50}$ The only exception would appear to be article I (b) of the Hague Convention on the Conflict of Laws Relating to the Form of Testamentary Dispositions, of October 24, 1960, 9 AM. J. Comp. L. 705 (1960), which provides that a testamentary disposition shall be valid as to form if it complies with the internal law of " $a$ nationality possessed by the testator, either at the time when he made the disposition, or at the time of his death" (cmphasis supplied). 
conduct and to limit his freedom. Especially if these restrictions take the form of prohibitions, individuals can easily obey the regulatory laws of several states without becoming involved in a conflict of duties. It consequently is an undeniable fact that already outside of the area of private law, there is a greater likelihood of the existence of legal restraints on the freedom of action of persons engaged in transnational activities than there is for persons engaged in activities restricted in all respects to one state. Under these circumstances, the alternative application of the torts laws of several states to a multiple-contact tort does not amount to discrimination.

It is submitted that the effects on contracts of legislation restricting human freedom in furtherance of the public interest have to be judged in a like manner. Questions as to impossibility or invalidity due to legislative prohibition of acts of performance cannot be determined by the application of one law alone. Rather, all legal orders with which the contract at hand is connected have to be searched for prohibitions of the act of performance called for by the agreement of the parties. If any of the states affected does have such a prohibition (applicable under its own proper law to the instant case by virtue of its contact with that state), the lex contractus will have to determine whether there is a moral impossibility of performance in view of the proscriptive rules of one of the various pertinent laws, the consequences of such impossibility for the validity of the contract, damages for nonperformance, and the like-unless a further step is taken, and the determination of these consequences is left to the state whose public law prohibits performance in the instant case. ${ }^{60}$

Even if the application of the regulatory legislation of several states to multiple contact cases thus does not constitute a discrimination against single contact cases subjected to only one legal order, the different treatment of multiple contact cases is possibly further restricted by the requirement that regulatory legislation be given effect only within the scope that it assigns to itself. In extreme cases, this can lead to the situation that a multiple-contact contract will escape the regulatory laws of all the states with which it is connected, because none of these laws apply to the particular case at hand. ${ }^{61}$

At first sight, rules that determine the law to be applied by organs of the forum state to acts affecting status but that make the exercise of jurisdicion in such cases

${ }^{00}$ The Federal (Supreme) Court of West Germany seeks to avoid these problems by generally rejecting the applicability of foreign public law to private law disputes, and permitting an exception only when a foreign state has already taken action under its public law within its own territory. Decision of September 17, 1959, [x960] Neue JuRistische WochenschrifT Iror. The Court overlooks that courts of almost all states have "indirectly" applied foreign public law, e.g., when deciding if the performance of a contract was "impossible" or if an allegedly tortious act was "illegal."

${ }^{01}$ Take, for instance, a contract connected with several states, each of which has legislation outlawing the gold clause. Still, the specific connecting factors selected by these states for the applicability of their respective gold clause acts may be lacking. This is not to indicate our approval of the theory that "international contracts" can, on principle, not be subjected to the gold clause legislation of any one state.

Modern legislation dealing with restrictive trade practices also frequently regulates only the internal market. It is therefore possible that contracts in restraint of "international" markets are not reached by the antitrust act of any state; see Mr. Justice Frankfurter, dissenting, in Timken Roller Bearing Co. v. United States, 34x U.S. 593, 605-06 (I95I). 
dependent upon the recognition of such acts by a specific foreign state, also discriminate against multiple contact cases. If the state thus selected will recognize the act in question only where this act is based on the application of the law chosen by its own choice-of-law rules, there will be, in the result, a cumulative application of the choice-of-law rules of the forum and of the foreign state whose recognition of the action to be taken is made decisive. But here, the stigma of discrimination is possibly removed by the consideration that the purpose of such a rule is to prevent, in the interest of the parties themselves, so-called "limping" legal relationships which are valid "domestically"-i.e., under the law chosen by the forum's choice-of-law rule -but invalid "abroad," i.e., under the law that another state would apply to the relationship in question. For instance, German law attempts to prevent matrimonium claudicans by making jurisdiction to grant divorces to aliens contingent upon the recognition of such divorces by the national law of the husband. ${ }^{62}$ In this connection, it is assumed that the national law of the husband recognizes the existence of the marriage that is to be dissolved. Divorce in Germany is thus made more difficult in order to save the parties from the problems encountered by those who live in a matrimonium claudicans. If, for instance, the national law of the husband makes its recognition of the divorce depend upon the German court's applying the substantive divorce law that is applicable under the foreign state's choice-of-law rules, the ultimate consequence of the condition imposed on the exercise of divorce jurisdiction by German courts with respect to aliens will be that aliens can obtain divorces in Germany only whenever such divorces are available under the laws chosen by both the German choice-of-law rule and that of the husband's national law.

German law could, and perhaps should, apply its policy against matrimonizm claudicans not only to the divorce of aliens, but also to their marriages: The competence of German civil status officials to perform marriages of aliens could be made contingent upon the recognition of such marriages by the national law of the husband-or, indeed, by the national laws of both spouses. As regards capacity to marry, such a condition already exists by virtue of a choice-of-law rule subjecting matrimonial capacity to the respective "whole" national laws of both spouses (i.e., subject to a possible renvoi to German law). Thus, if $X$, a national of $A$, wants to marry $Y$, a national of $B$, in Germany, then-assuming that the laws of both $A$ and $B$ prohibit bigamous marriages-a German civil status official will, for instance, have to examine whether $Y$ is validly married to a third party, i.e., whether his marriage to such a third party has been validly dissolved. The German civil status official therefore does not merely have to determine whether Y's divorce will be recognized in Germany, for example in an action for support. He also has to determine whether both $A$ and $B$ will recognize Y's divorce as restoring his matrimonial capacity.

s2 Section 606(b)(r) of the West German Code of Civil Procedure, as amended. 
As to form, however, German law ${ }^{63}$ provides that marriages within Germany can be celebrated only in German form unless both prospective spouses are aliens and the national law of one of them permits a consular-type marriage in Germany. But German law also makes the performance of the marriage ceremony by German civil status officials mandatory even if the home state of one or both of the prospective spouses will not recognize a marriage entered into in Germany in local form (i.e., by civil ceremony) by its nationals. It might seem advisable here to devise a rule that, while making the observance of German marriage formalities obligatory within Germany, empowers German civil status officials to refuse to act where the marriage would not be recognized in the home states of the respective spouses, ${ }^{64}$

In any event, it follows from the very nature of multiple contact cases that a legal relationship might be treated as valid by one state and invalid by another. If the choice-of-law rules of a state take this basic fact into account, especially by making provision, in the properly understood interest of the parties, against the creation of "limping" legal relationships through a cumulative application of several laws, this is not necessarily a discriminatory treatment of multiple contact cases. There is even less reason to talk of discrimination where the lex causae merely takes the applicability of a different law to the same transaction in other states into account as a mere fact (e.g., as a ground for the impossibility of contractual performance).

Suppose, on the other hand, that a choice-of-law rule takes into consideration all legal orders connected with a multiple-contact case (or, possibly, only those laws that claim application under their indigenous choice-of-law rules), but ultimately only selects a law that creates a new right or permits the modification of an existing right, excluding from applicability all potentially relevant laws that do not create rights or permit the modification of pre-existing rights. Such a rule, in our opinion, would hardly be compatible with the postulate of equal treatment for single and multiple contact cases. The first-mentioned variant of such a rule would, in substance, be identical with Niboyet's theory that the forum should, besides applying the substantive law chosen by its own choice-of-law rules, also recognize all rights created under foreign legal systems that, pursuant to their indigenous choice-of-law rules, assert their applicability to the case at hand. ${ }^{65}$ This view is related to a theory to be found in the interterritorial law of some pluri-legal states, which calls for the recognition throughout such states of all subjective rights-e.g., marriages-validly created in one of their political subdivisions in accordance with the latter's local choice-of-law rules. $^{\text {Bo }}$

${ }^{03}$ Article 13, section 3 EGBGB; section I5a of the Marriage Law of February 20, I946.

at This, however, is not the law; see the decision of the Kammergericht (Supreme Court of West Berlin) of September 14, 196I, [196x] NeUe JURISTISCHE WoCHENSCHRIFT 2209.

${ }^{a t}$ Article 53 of the preliminary draft of the Commission for the Reform of the French Civil Code provides: "A moins que la loi française ne fût compétente, toute situation juridique créée à l'étranger en vertu d'une loi étrangère qui se reconnaissait compétente, produit ses effets en France." This provision has been understood by the Comité de Droit International Privé as referring to the "creation" of private rights.

${ }^{\circ 0}$ See the decision of the Supreme Court of Poland of September I7, r924, German translation in 2 ZEITSCHRIFT Für OSTEUROPÄISCHES RECHT 53 (I926). 
Where rights are created by judgment or quasi-judicial administrative decision (e.g., adoption, divorce), there frequently is discrimination in favor of multiple contact cases: competence to create such rights is often not limited to states whose law supplies the lex causae, but the forum state is ready to recognize foreign judgments or quasi-judgments of states that are not competent to act under the lex causae, even if the law actually applied differs from that which would have been chosen by the forum state. It is well known that this enables rich persons to maintain or to establish contacts with several jurisdictions, so as to be able to obtain divorces or to make adoptions that would not be available to poorer parties who have contacts with only one state. This discrimination would be avoided if the recognition of foreign status judgments were made contingent upon their being based on the law applicable under the forum's choice-of-law rules. A further step in this direction would be to limit such recognition to judgments based on the law selected by the choice-of-law rules of the lex causae, while at the same time letting the forum create, modify, or terminate status rights again only in accordance with the law which the whole lex causae would apply.

\section{Discriminatory Treatment of Multiple Contact Cases Through the Application of a Special Substantive Law?}

It has been shown above that the technique of singling out one element of multiple contact cases and subjecting them only to the law thus indicated, finds its underlying justification in the attempt to accord equal treatment to substantially identical single and multiple contact situations. Nevertheless, this method, which has been called the "nationalization of transnational legal relationships," a significant objection: Especially where such transnational relationships have different types of contacts with not two, but with three or more states, it is extremely difficult to demonstrate that one of these laws-and only one of them-is the law most suited to the entire legal relationship. It has therefore been asserted that the transnational character of such legal relationships, i.e., their connection with many different states, is incompatible with their subjection to one single legal order. ${ }^{08}$ If it is not for this reason decided to apply several legal orders alternatively or cumulatively, it might still be possible to meet this basic objection by selecting a separate proper law for each of the different aspects or parts of a transnational relationship. Instead of choosing one law to govern the entire contract, for instance, separate choices of law can be made for various facets of formation-capacity, form, and the like-as well as for the various phases of execution, such as the consequences of nonperformance. This phenomenon of the so-called specialization of choice-of-law rules is based at least in part on the view that it is easier to make a rational choice between different laws if the choice-of-law question is broken up into several subquestions.

\footnotetext{
${ }^{07}$ Ernst Steindorff, Sachnormen im internationalen Privatrecht (1958).

${ }^{08}$ STEINDORFF, op. cit. supra note 67 , passim.
} 
But there is also a different way of approach: that of discarding this frequently tortious subjection of multiple contact cases to a single national law, which obviously is designed primarily for single-contact cases, and applying a special substantive law instead. Such a special law can be created by treaty, e.g., by an agreement creating a special law of sales to govern the international sale of goods. ${ }^{6 \theta}$ A special substantive system of law for multiple contact cases could also be developed by the forum through judicial legislation, as was the ius gentium of the Romans; and it seems not impossible to imagine that even today, some state might enact a special system of private law to govern not only multiple contact cases connected with the forum and with other states, but also cases connected with more than one other state but with no forum contacts. In interterritorial and interpersonal law as well, it sometimes happens that the central authority enacts special substantive laws to govern social relationships connected with several political subdivisions or population groups. ${ }^{70}$

In modern private international law, the application of a judge-made special body of laws to "international" multiple contact cases seems particularly appropriate where a choice-of-law rule normally intended to select the internal law of a state leads to an international entity, especially an international organization. Take, for instance, a case normally governed by the law of the flag of a vessel or by the "national law" of an airplane. If an international organization had power to operate ships or airplanes under its flag and registry, the international character of the organization and the rule of "equidistance" from all members would strongly militate against attempts to attribute some "nationality" to the vessel-e.g., by selecting the place of construction-merely to ensure the application of some national law. If the international organization has no private law system of its own, it would seem that the general principles of the laws of its constituent states will have to be regarded as the law of the flag or registry. Similar considerations apply to a choice-of-law rule that normally subjects the liability of a state for the torts of its agents to the law of that state. If the liability of an international organization for the torts of its agents is at issue, the organization's "own" law will have to be found in the general principles of the torts law of its member states. However, the shaping of ad hoc quasi-national law rules for an international organization by a synthesis of the apposite laws of its member states is not to be understood to be synonymous with the cumulative application of the laws of the latter. If the European Economic

"Treaties creating a special substantive law for "international" sales or "international" transports (a law that has to be applied to such transactions by all signatory states), do not cover all sales or transports having some contacts with several states. They merely deal with situations that are regarded as "critical," i.e., expected to lead to overlapping claims of legislative jurisdiction. The result is that many multiple contact cases with patently intensive links to one state are not covered by the treaty but "reserved" for regulation by a national law. The difficulties of distinguishing between transnational transactions to be subjected to a uniform legal régime and not fully heterogeneous situations reserved for national regulation is made apparent when seen in the light of American discussion of the applicability of federal regulatory legislation to "intrastate commerce affecting interstate commerce," see Kallis, Local Conduct and the Sherman Act, 1959 Duxe L.J. 236.

${ }^{70}$ Thus, in the United States, Congress can enact private law rules governing interstate commerce.In states where the various religious denominations have jurisdiction to regulate matrimonial law, the central legislature might enact legislation governing marriages between spouses of different religion. 
Community is responsible for the torts of its agents in accordance with the principles of government tort liability common to its member states, ${ }^{71}$ this does not mean that the Community is liable only after liability has been established in each individual case under the laws of all member states. This would be a palpable discrimination in favor of international organizations as compared to states. ${ }^{\mathbf{7 2}}$ It therefore seems appropriate to regard this reference to the general principles of the law of the member states in the European Economic Community treaty as an authorization for the judicial shaping of an ad hoc government torts law of the Community by borrowing from apposite rules of the law of all or most member states.

Conceivably, the courts might be more generally authorized to develop the pertinent "rule of decision" for multiple contact situations in the form of an ad hoc law based on a synthesis of potentially relevant laws. A weighty objection against such a mode of procedure is that the ultimate judicial decision would then be even less predictable than it is already under existing choice-of-law rules that point to a single legal system. Even today, courts often base their decisions of multiple contact cases on rules that were not, or could not have been, taken into consideration by the parties. Still, it seems appropriate to avoid making the outcome of multiple contact cases still less predictable than it is already ${ }^{73}$ However, if transnational legal relationships are subjected by treaty to a codified $a d$ hoc law based on synthesis of potentially relevant national laws, this can hardly be regarded as a discriminatory treatment of multiple contact cases as compared to single contact cases.

Difficult problems arise if a state, while subjecting multiple contact cases to one single law chosen on a basis of parity, applies not the law normally governing indigenous single contact cases but a special régime of substantive law to those cases in which its choice-of-law rules point to the lex fori. A well-known example of such a situation is afforded by Egypt under the Mixed Codes: The Mixed Courts

${ }^{71}$ See article 215 of the European Economic Community treaty.

72 This is overlooked by ANDREas Heldrich, Die allgemeinen RechtsGrundsïtze der ausserventrugLICHEN HAFTUNG IM BEREICH DER EUROPÄISCHEN WIRTSCHAFTSGEMEINSCHAFT I9 (I96I), who interprets article 215 as referring to the law most disadvantageous to the injured party. But see Daig, Die Gerichtsbarkeit in der Europäischen Wirtschaftsgemeinschaft und der Ettropäischen Atomgemeinschaft, 83 ARChiv des ÖFFENTLICHEN REChts 132, I84 (1958).

${ }^{73}$ If each state were to develop its own ius gentium for multiple contact cases, the likelihood of harmony between the rules of such iura gentium of different states would be even smaller than is the probability that the operation of the various systems of private international law in effect at the present will lead to the application of the same national law in the various states. On the other hand, if the law to be applied to certain multiple contact cases is developed primarily by the custom of the parties, or if disputes arising from such cases are adjudicated by international courts or private arbitration tribunals, the ground will be better prepared for the development of such an internationally harmonious itss gentium.

We have already maintained in 1939 that the parties to a contract that is connected with scveral states can not only choose the law of one of these states by virtue of their party autonomy, but that they can also reject the applicability of any such national law as inappropriate. Wengler, Die Ankiipfung des zwingenden Schuldrechts im internationalen Privatrecht, 54 ZeITschrift Für vergleicheNDE Rechtswissenschaft 168, 210 et seq. (r94I). Similar views are advanced by Philip C. Jessup, Transnational Law (I956), and by McNair, The General Principles of Laty Recognized by Civilized Nations, 33 BRIT. Y.B. INT'L L. I (1957). Especially non-public international law contracts between states or international organizations on private law matters are possibly subject, by virtue of the intention of the parties, only to the general principles of law recognized by civilized nations or to special rules based on a synthesis of the national laws of the contracting states. 
first had to decide whether under Egyptian private international law, foreign law or "Egyptian" law applied. Where the latter was the case, there had to be a further choice between the Mixed Code and the Native Code which turned on the presence of a "mixed interest," i.e., the involvement of an alien.

An ad hoc substantive law for cases connected both with the forum state and with foreign states must also be said to exist where a state, while generally applying the law governing indigenous single contact cases to multiple contact cases that are assigned to regulation by its own law, does so subject to some modifications. These are usually referred to as the "law of aliens" or as "special rules for foreign transactions."74 To give an example: Probably all states apply "the" lex rei sitae to contracts for the sales and transfer of domestic immovables. But if the vendor or purchaser is an alien, such transactions are usually complicated by special requirements, e.g., obtaining a license, and possibly also by more stringent form requirements (it is also possible, of course, that such transactions with or by aliens might be made easier than wholly indigenous transactions of the same kind). Another situation where a state applying its own law to multiple contact cases is in reality applying ad hoc rules of substantive law can be found in requirements for the form of wills disposing of domestic immovables. A state that makes its own law applicable to the form of wills disposing of domestic immovables, as well as to the form of all public wills made with the participation of its own public authorities, might still have special form requirements for wills made by aliens in the forum state, or for wills made aboard its own ships on the high seas or in foreign ports. ${ }^{75}$ It is also possible to visualize a state that applies its regular law of sales only to goods to be manufactured and consumed at home, while having a special law of sales for import and export sales that are subject to "its own" law. Another instance of the application of a special régime of substantive law to multiple contact cases subject to the lex fori is the case where aliens domiciled in the forum state are subject to "domestic law" but where the latter is different for various ethnic groups; here it is possible that the aliens living within a country are subjected to their own special ethnic law, as are the Chinese in Indonesia and in Burma.

If a state has created special substantive rules to govern all or part of the multiple contact cases to which it applies its own law (i.e., rules that differ from the substantive law that is applied to indigenous single contact cases), the question arises whether reference to the "law" of such a state by the choice-of-law rules of other states will also reach its ad hoc law for multiple contact cases. Let us assume that while the Mixed Civil Code and the Native Civil Code were in effect in Egypt, a French choice-of-law rule pointed to the private law of the State of Egypt (the law in effect "in Egypt"), and that there was no renvoi to French law (or that renvoi was not accepted). It seems clear that in such a case, a French court would have applied

\footnotetext{
7t Continental European authors usually draw a sharp distinction between choice-of-law rules and the law of aliens. Among younger German authors, especially StEINDORFF, op. cit. supra note 67, opposes this differentiation.

${ }^{75}$ See section 225 I of the West German Civil Code.
} 
the one or the other of these two codes in accordance with the principles of Egyptian law delimiting their respective scopes. Surely, the court would not have taken the position that only the Native Civil Code was "the" private law of Egypt, and that a reference to "Egyptian" private law had to be interpreted as pointing only to this purely "national" Egyptian law. Similarly, where an English choice-of-law rule refers to Indonesian law as the law of the domicile, an English court will have to apply the special legal régime of the Chinese inhabitants of Indonesia, if this special régime is applicable in casu by virtue of Indonesian interpersonal conflicts rules. ${ }^{70}$

Is the creation of an ad hoc law for part of the multiple contact cases connected with the forum state, and therefore subjected by it to the lex fori, tantamount to unequal treatment or even to discrimination? This question is raised usually where other states are generally willing to let their choice-of-law rules point to a state that has such a special substantive law for multiple contact cases. Objections against the application of the special private law of another state will be raised especially where it is asserted that this ad hoc régime for multiple contact cases discriminates against nationals of the forum state, against all aliens, or generally against foreign states. Whether there is "discrimination" will initially depend upon whether other states consider such an ad hoc régime to be in derogation of those interests which they have undertaken to protect. For unlike equal treatment, discrimination obviously has a subjective element that varies with time and place. It is conceivable that a state places value upon absolute equality in the treatment of indigenous and transnational relationships. Such a state will therefore maintain that if there are to be private law restrictions upon human freedom, these may not, at any rate, be limited to transnational activities. A state adopting this position will probably exclude the application of a foreign ad hoc law restrictive of transnational transactions by resort to the exception of public policy.

One common example of a special régime for multiple contact cases is a rule that grants relief to persons who, because of their foreign domicil or residence, are unable to take certain actions for the protection of their rights, or who cannot take appropriate action as promptly as can local domiciliaries or residents. This is the purpose of longer periods of limitation for actions by foreign residents, and also possibly for provisions deferring to the form requirements of the law of the domicile (although this latter type of provision is usually made unnecessary by a more liberal

\footnotetext{
${ }^{76}$ Note, however, the difficulties that can arise in this connection. Suppose, for instance, that State $A$ would apply the law of State $B$ to a multiple contact case having the connecting factor $X$, and that State $B$ has a special régime of law for multiple contact cases with the connecting factor $Y$. Now, a multiple contact case with the connecting factors $X$ and $Y$ will pose no problems, since both $A$ and $B$ will apply $B$ 's special law to it. But what of multiple contact cases with connecting factor $X$ only, and subject, in accordance with $B$ 's choice-of-law rules, neither to its general law, nor to its ad hoc transnational transactions law, but to the law of State $C$ ? If the choice-of-law rules of State $A$ reject this form of renvoi, the problem will be similar to that arising where State $A$ refers to State $B$, rejecting renvoi, and State $B$, a pluri-legal state, would not apply any of its territorial or personal legal systems to the case at hand. If State $A$ should persist in applying $B$ 's law despite the latter's disinterest, courts of State $A$ will have to develop their own interterritorial or interpersonal choice-of-law rules for State $B$ so as to apply one of its systems of law to the case at hand.
} 
choice-of-law rule pointing to the lex loci actus). Where such relief is not provided by statute, it might still be created, in the interests of justice, by judicial legislation. ${ }^{77}$ Surely, special rules of this kind for multiple contact cases cannot be regarded as discriminatory; they merely reflect the transnational character of the cases to which they apply. ${ }^{78}$

But there can also be other cases where restrictions imposed by a foreign ad hoc law on transnational activities may be regarded as beneficial to the forum state. Suppose that a foreign state has prohibited, or otherwise restricted, the export of certain types of goods to the forum state (or possibly also to other states), and that it treats contracts made in violation of such prohibitions as void while at the same time upholding wholly domestic contracts for the sale of the same goods. The forum still will have to inquire whether this regulation of exports really violates its interests, or whether the forum state itself might not have enacted restrictions upon imports if that had not been made unnecessary by the other state's export restrictions (e.g., regulations for the export or import of narcotics). If the latter is the case, the forum will not regard a foreign prohibition of exports to itself as an unfriendly act of discrimination; and it will consequently also apply a foreign ad hoc law invalidating such export sales. The provisions of the Bretton Woods agreement dealing with the application of the forign exchange regulations of other states are manifestly also based on the view that the restrictions imposed by one state in order to protect its own currency are in final analysis beneficial for other states as well, and that their application should consequently not be denied on grounds of discrimination.

It would also be difficult to speak of discrimination if a state, while assuming power to adjudicate divorce actions of aliens domiciled within its jurisdiction, applied different substantive divorce laws to its own citizens and to aliens or to the nationals of one particular foreign country, especially if this special divorce law for aliens were identical with, or similar to, that of their own countries. Suppose that a state asserts power to grant divorces to all of its domiciliaries, including Italians (Italian private law knows no divorce). Why should Italy complain if such a state applied a more lenient law to its own nationals and a more stringent one-possibly one excluding divorce altogether-to Italians?

If a foreign ad hoc legal régime for multiple contact cases has a tendency to

${ }^{77}$ In recent years, courts in Western countries have repeatedly tried to accommodate Iron Curtain residents who for political reasons were unable to execute instruments in public form with respect to their properties in the West. In some such cases, informal declarations were accepted as the equivalent of the publicly acknowledged instruments required by the lex causae.

${ }^{78}$ Pursuant to article 12 of the Geneva Convention of July 28, I95I, Relating to the Status of Refugees, 189 U.N.T.S. 150, issues relating to the personal status of refugees have to be decided in accordance with the "law" of the state in which they are now domiciled. It is hardly the sense of the Convention that this "law" could include the choice-of-law rules of the refugec's domiciliary state where these rules refer to another state; and in any event, the domiciliary state is not permitted to apply, by virtue of its choice-of-law rules, the refugee's national law. But is the obligation of the domiciliary state to assimilate refugees incompatible with the enactment of a special law for a particular group of refugees, especially if this law takes into account the legal traditions of the group with which it deals? 
disadvantage aliens as compared with citizens (e.g., by making the purchase of real estate more difficult for aliens than for its own nationals), this is generally regarded as discriminatory. Other states that are, in principle, willing to apply the private law of a state which discriminates in this manner, may exclude the applicability of these discriminatory provisions of its ad hoc law by resorting to the exception of public policy. For example, if succession is governed by the national law of the decedent, such provisions of that law as exclude aliens from succession would be disregarded. On the other hand, however, there would be no objection to the application, under a choice-of-law rule pointing to a foreign law as regards form requirements for wills, of special requirements imposed by the appropriate foreign state for wills made aboard ships flying its flag. Incidentally, if a state refuses to apply foreign ad hoc multiple-contact substantive rules because these are discriminatory, that will lead to the application of the nondiscriminatory rules of the proper law designed for single contact cases-not to the application of the lex fori.

The enactment of special laws for multiple contact cases connected with the forum and with other states because of the nationality of the parties or by virtue of other contacts might in some instances be prohibited by treaty. Such special laws are covered by treaty prohibitions of "national discriminations" if the enacting state intends them to be discriminatory in this way, and if they are so regarded by other states. A state that is party to a treaty prohibiting discrimination on grounds of nationality will of course not apply special legislation of another state enacted in violation of the latter's treaty obligations. Conceivably, the forum might also be obligated by a multilateral agreement not to give domestic effect to the discriminatory laws of a state that is not itself a party to the agreement. ${ }^{79}$

An indirect legislative discrimination against aliens is the following: A plurilegal state has several discrete legal systems for different indigenous ethical groups, and one of these legal systems places the members of the group subject to it at a disadvantage when compared to members of the other groups. Now, aliens involved in multiple contact cases with contacts to the forum are made subject to that system of indigenous law. which places those governed by it in the worst comparative position. This type of indirect discrimination is not likely to gain additional support abroad through recognition and enforcement by the state of such aliens' nationality. However, whether it amounts to a violation of the standard national treatment clause in establishment conventions is quite another question. If the national treatment clause provides that nationals of the other contracting party are to be treated in the same manner as "citizens" but if citizens themselves are not treated equally,

${ }^{78}$ A decision of the Kammergericht (Supreme Court of West Berlin) of September 14, 196r, [196r] NeUE JURISTISCHE WochenschrifT 2209, dealt with the question whether a provision of Iranian law requiring prior official consent for marriages of certain classes of Iranian nationals can be applied in Germany in the face of the European Convention on Human Rights. The Court held that the Convention did not stand in the way of the application of this rule of Iranian law in Germany, because Iran is not a party to the Convention. But, it would seem, the European Convention on Human Rights malies illegal all restraints on marriage on the grounds of nationality in a member state, even if the prospective spouses are not nationals of member states. 
the national treatment clause alone will not signify that those protected by it may not be classified with the lowest group, and still less that they must be assimilated to that indigenous group which receives the most preferential treatment. The same observations probably also apply where the aliens do not possess those characteristics which are determinative for the classification of citizens into different groups, ${ }^{80}$ and where the aliens must consequently be assimilated rather arbitrarily to one group or the other. Wherever this manner of circumvention of treaty standards of equality is within the realm of possibility, the draftsmen will have to cope with it through appropriate refinements in the text of the national treatment clause. This will also be the case where the treaty in question does not merely bar discrimination against aliens but all "national discriminations."

In any event, it cannot be said that all states always reject the application of those provisions of an otherwise applicable foreign law which are ad hoc private law rules discriminating against aliens or foreign countries. Curiously enough, there seems to be a willingness to apply such foreign rules where the forum has analogous rules that discriminate in the opposite direction. Suppose, for instance, that in accordance with the choice-of-law rules of State $B$, a contract for the sale of a certain object of artistic value is governed by the law of State $A$. Now, if State $A$ requires a special license for the sale of such objects to aliens, or if it stipulates a lesser liability of the vendor for genuineness when the object is sold abroad, a court in State $B$ might possibly be willing to recognize these special limitations if the law of State $B$ has analogous provisions governing export sales of art objects. Similarly, as is well known, states with currency legislation restrictive of transnational transactions are more likely to apply corresponding restrictions of other states-especially of those states which in casu furnish the proper law of the contract-than are states that have no currency restrictions at all. Thus, the bad conscience of states can lead to a perversion of the idea of equality: A state that discriminates against aliens or against multiple-contact transactions might apply the discriminatory legislation of another state aimed against itself or its own nationals, fearing that any other conduct will give rise to the objection that the pot is calling the kettle black.

\section{Public Policy as a Manifestation of the Principle of Equality}

It has already been pointed out in the first part of this paper that the public policy clause is an especially important device for the discriminatory reduction of the scope of foreign law and, usually, for a simultaneous expansion of the reach of domestic substantive law beyond what is provided for by normal, nondiscriminatory-and sometimes even by discriminatory-choice-of-law rules. This is not only the case if the public policy clause is understood as a primarily negative conflicts rule that

${ }^{80}$ Where a state that is obligated to extend national treatment to aliens has different systems of private law for different religious denominations, it must apply to its alien domiciliaries the law of their respective religious denominations, where available. But the national treatment clause does not obligate such a state to delimit the respective scopes of the various systems of religious law enforced by it on the basis of parity. 
provides for the inapplicability of the foreign law normally chosen under certain conditions, and fills the gap thus created with the lex fori, but also if "public policy" is used to describe the situation where a certain substantive rule of domestic law is regarded as so important for the public interest that it is given an unusually wide reach, e.g., that it has to be applied wherever a local court has jurisdiction.

Let us first discuss the former version of the public policy, which can be said to be the prevailing one, at least in Germany. Here, a rule of foreign substantive law that is normally applicable may not be applied because the content of that law, as judged by the legal system of the forum state, appears objectionable, and because at the same time there is a direct connection of the case with the forum state. This direct connection is a relationship with the domestic order which is usually not defined in codifications of the public policy clause, and which the judge has discretion to find in the circumstances of individual cases. If there is such direct connection, the application of the objectionable foreign law to the case at hand by a domestic court would be deemed intolerable. ${ }^{81}$

While it seems theoretically possible to empower the courts to examine rules of the lex fori with a view to determining whether their content is objectionable, and while it thus appears also possible, in theory, to combine a judicial power to refuse the application of "immoral" domestic laws ${ }^{82}$ with a similar power to refuse the application of "objectionable" foreign laws, no system of law currently in existence has chosen this path. The public policy clause has remained an exceptional rule directed solely at foreign law. Still, it seems possible that the pejoration of foreign law inherent in the notion of public policy might be, so to say, counterbalanced by other general clauses covering choice-of-law rules directed at foreign law. Again, such a solution has not been attempted anywhere.

That the public policy clause is based on a discriminatory approach towards foreign law follows from the simple fact that objections to the content of the foreign law are measured in terms of the lex fori. A state that recognizes polygamy in its internal legal system cannot refuse the application of foreign polygamous marriage law as such on grounds of public policy. If a state permits polygamy only for certain groups of persons ${ }^{83}$ or only within a certain geographic area (i.e., as a practicaI matter, primarily in the colonies of European states), it still might be permissible for the choice-of-law rules of such a state to reject the application of foreign polygamy laws in those parts of its own territory where polygamy is not permitted. But a good deal of hypocrisy would be required to justify the rejection, as objectionable on public policy grounds, of the application of foreign polygamy law in a territory where polygamy is permitted to parts of the forum state's own population.

${ }^{81}$ At least in Germany, this is the current formulation of the public policy clause. The criticism directed against this formula by Lagarde appears to us as unfounded. See Paur Lagarde, Recherches. SUR L'ORDRE PUBLIC EN DROIT INTERNATIONAL PRIVÉ 55 et seq.; 104 et seq. (1959).

ss There has been some natural law thinking along these lines in recent years, especially in West Germany. See generally Hans-Ul,Rich Evers, Der Richter und das unstTtuiche Gesetz (1956).

${ }^{83}$ Whether this, in turn, is compatible with a constitutional standard of equality, has been the subject of discussion in India; see Wengler, supra note $\mathrm{r}_{4}$, at 253 n.22. 
A state that is generally willing to take into account the choice-of-law rules of other states might find occasion to react adversely to another state's discriminatory expansion and retraction of the respective spheres of foreign and domestic law by resort to the public policy clause. Suppose, for instance, that State $A$ determines capacity to marry cumulatively in accordance with the respective national laws of the prospective spouses, and assume, further, that State $A$ generally accepts renvoi. Now, if one of the prospective spouses happens to be a national of State $B$ but domiciled in State $A$, and if according to State $B$ 's choice-of-law rules, the law of the domicile governs capacity to marry, State $A$ would, in accepting the referral back, ordinarily apply its own law. But suppose, further, that a court of State $B$ would, mutatis mutandis, refuse to apply the substantive marriage capacity law of State $A$ on public policy grounds. This raises the question whether a court of State $A$ should, in turn, recognize this exception from State $B$ 's ordinary choice-oflaw rule, based as it is on the notion that State $A$ 's law is there regarded as "objectionable" or possibly even as "immoral." One purpose of renvoi is to protect the parties from conflicting decisions of the same case in different countries. Surely, this objective militates in favor of acquiescing in State $B$ 's public policy-based exception from the lex domicilii and applying the substantive law of State $B$-the law that is generally applicable under State $A$ 's choice-of-law rules, anyway. On the other hand, it not only seems hardly appropriate for a court to repeat a foreign negative value judgment as to its own law, but it also appears objectionable to aid a foreign state in the discriminatory treatment of foreign and domestic law, especially where the forum places a high value on the principle of equality. But the logical consequence of this latter line of reasoning is the rejection, by State $A$, of its own public policy clause. Only the notion that discriminations in domestic law justify discriminations in foreign law will support taking into account foreign public policy in our hypothetical case.

Similar considerations apply where the private international law of a state in principle is ready to apply the law of another state to certain multiple contact cases (i.e., to situations with ingredients that, under standard choice-oflaw rules, constitute contacts with more than one legal system), but where it peremptorily excludes the applicability of some rules of foreign law. For instance, German private international law provides that a contract between spouses as to marital property is governed by the national law of the husband at the time of marriage, even if the husband later changes his nationality. But it also provides that a rule of foreign law barring marital property contracts during coverture will not be applied if either the husband has acquired German nationality or the spouses have established their domicile in Germany. ${ }^{84}$ Conversely, German private international law insists that spouses who are German nationals at the time of marriage can, during coverture, continue to contract with respect to their marital property rights even after they acquire foreign nationality or a foreign domicile and the law of their new

\footnotetext{
${ }^{84}$ See article 15 EGBGB.
} 
nationality or domicile prohibits marital property contracts during coverture. Now suppose the private international law of another state, e.g., England, applies the latest lex domicilii to marital property but accepts renvoi. Would an English court regard a post-nuptial marital property contract of French spouses now domiciled in Germany as valid because the German choice-of-law rule generally refers to French law but not to the French rule as to the invalidity of post-nuptial marital property settlements? We are again faced with the question whether or not a unilateral discrimination against the substantive law of other states by a foreign choice-of-law rule should be respected. If the private international law of the forum state is especially scrupulous with regard to the parity of foreign and domestic law, it will refuse to aid other states in the enforcement of their unequal choice-of-law rules. ${ }^{85}$

Remarkably enough, the comparison required by the public policy clause between the relevant rule of foreign law and the corresponding rule of domestic law in final analysis amounts to nothing else but another application of the principle of equality. The following line of reasoning will reveal this more clearly: The vast majority of the cases arising in a state that in principle is willing to apply foreign law, involve single contact cases (i.e., situations connected to only one legal order by standard criteria), for which the application of the lex fori is routine. Furthermore, most situations having contacts with several states that become subject to domestic litigation have some connection with the forum state. Now, all multiple contact cases are subjected to their appropriate laws, foreign or domestic, by the normal choice-of-law rules. The mere fact that through this process, legal questions of a like nature-e.g., the validity of a marriage or of a contract-are decided according to different legal standards by the same court, does not of itself amount to unequal treatment. Were it otherwise, the courts of every country that recognizes the principle of equality would always have to apply the lex fori; and there would be no more private international law. But the public policy clause does become operative as soon as the substantive differences between a rule of foreign law and lex fori become grossly excessive-always provided that the presence of a connection with the forum state makes it necessary to attribute importance to such a divergency. The decisions of the courts of various states on constitutional law show that it is primarily the "arbitrary," i.e., the excessively different treatment of like circumstances that is regarded as violative of constitutional standards of equality. ${ }^{86}$ But such a grossly

${ }^{88}$ A similar question could arise in connection with the rule of Netherlands private international law that does not recognize holographic wills of Netherlands nationals made outside of the Netherlands, while generally permitting Netherlands nationals to make their wills abroad in accordance with the lex loci actus. Even states whose choice-of-law rules refer to the whole foreign law will seldom have occasion to apply this Netherlands choice-of-law rule. Still, some state might both subject the form of wills exclusively to the lex successionis and refer to the whole foreign law. But before such a state could reject the Netherlands rule mentioned here as discriminatory, it would have to examine whether Netherlands conflicts law would, in turn, respect the prohibitory rules on the form of testation that other states might have as regards wills made by their nationals in the Netherlands.

${ }^{80}$ See especially the Swiss decisions on the subject of equality discussed in Fritz Fleiner \& Zaccaru Giacometti, Schweizerisches Bundesstaatsrecht 414 (I949). 
excessive unequal treatment of basically similar cases is at the same time the criterion for the applicability of the public policy clause.

Now, the degree of variation between the lex fori and the foreign substantive law normally chosen that is necessary to make the public policy clause applicable differs not only from state to state but also from case to case: negative reactions to foreign law are directly proportional to the intensity of impact on the forum. A state that has several territorial or personal legal systems can more readily put up with a foreign law at variance with its own laws than can a state that itself has only one system of substantive law. But even in states with a uniform legal system, the point where the divergencies between foreign and domestic law become objectionable is not the same. States that have, in the course of peaceful development, repeatedly made incisive changes in their legal systems and are ready to make further such changes in the future, will not react as intensively against divergencies between foreign and domestic law as will states that have conservatively adhered to a specific legal order for a substantial period of time.

Judicial opinions do not always clearly reveal that it is the strongly different, grossly unequal treatment of multiple contact cases, as measured against both the treatment of single contact cases and of multiple contact cases subject to the lex fori, that activates the public policy clause. Take the following example: In German private international law, the proper law of an engagement to marry, including breach of promise, is the national law of the defendant. This same law consequently also governs, at least in principle, the financée's claim based on section 1300 of the Civil Code. ${ }^{87}$ But if the national law of the prospective husband does not grant a claim of this kind, a woman who is a German national is still held to be entitled to raise a claim based on section 1300 in conjunction with the public policy clause.

The Federal Supreme Court justifies this result by stating that it is designed to avoid "inequitable discrimination against a German fiancée as compared with an alien woman who has been engaged to a German." The result is to be different, however, if the national law of the man "is relatively only insignificantly different from German law." 88 In other words, the multiple contact cases are compared to one another. If it is found that the results obtained by the application of foreign or domestic law diverge especially strongly, foreign law is excluded from application to those cases in which there is a connection with the forum that differs from the one serving as the criterion for the choice of law-in the instant case, the nationality of the plaintiff.

Similarly, the so-called "special public policy clauses" of German private international law $w^{80}$ often are aimed at guaranteeing that especially a German national shall not be discriminated against through the application of the foreign law that

\footnotetext{
${ }^{87}$ This section gives the previously chaste fiancée compensation for suffering and humiliation due to seduction when the male betrothed has culpably broken the engagement or caused its termination.

${ }^{88}$ Decision of November 21, I958, [1959] NeUE JuRistische Wochenschrift 529.

${ }^{88}$ See, e.g., article 12 EGBGB, discussed supra at note $4^{\circ}$.
} 
would normally govern; such discrimination being measured by reference to the treatment of other nationals of the forum state who are involved only in homogeneous situations or in heterogeneous situations governed by the lex fori. By attempting to secure the equal treatment of the forum's own nationals in situations involving the same legal questions but having contacts with different states, these special rules of course violate, as has been pointed out above, ${ }^{90}$ the postulate of the equal treatment of the various legal systems; at the same time they discriminate against aliens.

In so far as the public policy clause works to prevent the operation of the law normally referred to by equal choice-of-law rules when the forum's own nationals are disadvantaged by the "proper" law but does not come into play where the "proper" law favors such nationals, we believe it to be incompatible with the national treatment clauses of settlement conventions. However, where the public policy clause cuts down the scope of a foreign legal system in a discriminatory manner but is not made operative by the criterion of the domestic nationality of one of the parties, the national treatment clause is ineffective.

If the law applied to fill the gap created by the operation of the public policy clause is filled not by the lex fori but by another rule drawn from the law that is normally applicable, ${ }^{01}$ or by a special rule designed for this contingency, the discriminatory treatment of foreign and domestic law so characteristic of the public policy clause seems not quite as apparent.

A school of thought that is presently on the wane gives the following meaning to public policy: certain rules of the lex fori are so important as to be universally applicable, i.e., they have to be applied wherever a legal question regulated by them arises in the forum state. The application of foreign law is thus excluded even if the foreign law is identical with the lex fori. Manifestly, this version of the public policy clause, too, is a flagrant violation of the parity between foreign and domestic law.

This view of the public policy clause which does not proceed from the exclusion of foreign law to the application of the lex fori, but moves in exactly the opposite direction, sometimes appears in a milder version. Here, the scope of all or of specific domestic rules of law is not determined by bilateral but by unilateral choiceof-law rules which give expression exclusively to the public interest of the forum state or to the purpose of the rule in question. This suggests the question whether the choice-of-law rules of the forum could and should not also give effect to all foreign rules of substantive law which are made applicable on grounds of public interest by their own proper law, thus achieving an equal treatment of all legal orders. The idea that the scope of rules of law can be determined by resort to the "governmental

${ }^{\circ 0}$ See supra p. 823 .

${ }^{21}$ See, e.g., 106 Entscheidungen des Reichsgerichts in Zivilsachen 82 (1922), holding a Swiss statutory provision exempting certain pecuniary claims reduced to judgment from any prescription period at all to be contrary to German public policy, but directing the lower court to apply-if feasiblethe most apposite Swiss, rather than German, statute of limitations to fill the gap thus created in the lex causae. 
policy" of the power that has enacted them, and that the forum state should be ready to apply not only domestic, but also foreign rules of law within the scope indicated by such considerations, is familiar especially to American thinking on the conflict of laws. ${ }^{22}$ In any event, this leaves the possibility that several states enact conflicting laws, and that the respective scopes of these laws, as established by the public purpose to which they give expression, are in conflict. ${ }^{93}$ It seems likely that wherever there is such a conflict between a foreign law and lex fori, the latter will be applied. ${ }^{94}$ If there is a conflict between the laws of two foreign states, the spheres of which have been fixed by unilateral choice-of-law rules of their respective proper laws, the forum state would have to decide by objective and therefore necessarily by nondiscriminatory criteria which law is to prevail.

But it is also possible that, if the forum state should be willing to apply every foreign and domestic law within the scope assigned to it by the public interest of its proper legal order, it could cumulatively apply several laws. This is particularly the case with respect to rules that place restraints upon human action through prohibitons sanctioned by damages or by the nullity of offending transactions. For a regulatory law that does not itself proscribe a certain type of human conduct does not contain a negative clause providing that conduct not proscribed by it may not be prohibited by other rules of law. Treating the various states on the basis of equality would thus require that the private international law of the forum be willing to award reparations for the violation of such regulatory laws if any domestic or foreign private law system has prohibited the act giving rise to damages, provided that the case at hand is subject to a regulatory law as determined by its proper legal order, and further provided that the latter was competent, under public international law, to enact the law in question. The principle of parity would further require that the forum treat as invalid every contract the performance of which requires an act that has been prohibited by any state, again if the prohibition is applicable by the choice-oflaw rules of its proper law and if such rules are permissible under public international law.

The willingness to apply foreign and domestic regulatory legislation equally by cumulatively applying all laws that want to be applied ${ }^{95}$ would of course produce

${ }^{93}$ See Hancock, Choice-of-Law Policies in Multiple Contact Cases, 5 U. Tononto L.J. 132, 142 (I943): ".... whether the policies of the various state laws involved in a conflict problem can be reconciled or not, it is always most important that they should be given fair and tolerant consideration by the court of the forum."

${ }^{93}$ American authors are not always clear as to what is to happen if no state has a "governmental interest" in the application of its law to a multiple contact case. According to Currie, Notes on Methods and Objectives in the Conflict of Laws, I959 DukE L.J. I7, 178 , the forum would have to apply its own law particularly to these cases.

${ }^{01} \mathrm{This}$, in any event, is the opinion of Currie, loc. cit. in the preceding note.

os This theory, which has been advanced by us and has also been accepted by other authors, notably Konrad Zweigert and Karl H. Neumayer, has been attacked by FRANK VISCHER, KollisionsREChTLICHE Parteiautonomie und diRIGistische Wirtschaftsgesetzgebung $167 \mathrm{et} \mathrm{seq}$. (1960). If a contract is to be governed by the law of a specific state that supplies the "proper law of the contract," the effect attributed by that law to the economic regulatory legislation of third countries should certainly be taken into account. If, on the other hand, it is thought that subjecting a multiple-contact contract to one national law would be contrary to the special character of "international" contracts and if, accordingly, 
the result that states which assign their regulatory legislation a very pervasive scope could count on the application of their law by the forum state more frequently than could states which observe more restraint in extending the reach of their regulatory laws. But the requirement of equal treatment would be satisfied by the forum's willingness to apply the law of any state that wants its law to be applied.

Of course, it is quite likely that foreign regulatory legislation follows a pattern of national discrimination by seeking to reach only cases having certain contacts with other states. Where this is the case, the problem will be substantially one of reaction to foreign ad hoc rules subjecting multiple contact cases to discriminatory treatment; ${ }^{96}$ this has already been discussed above..$^{97}$

\section{ConcLusion}

Perhaps the most significant insight to be gained from the above examinations into the significance of the idea of equality for choice-of-law rules is that the application of this idea can, as viewed under different aspects, lead to conflicting results. In other words, there can be antinomies of the realization of the idea of equality in private international law. A particularly striking antinomy is inherent in the public policy clause which, while patently discriminating against foreign law in favor of the lex fori, still is founded in the desire to prevent excessive discrepancies in the treatment of similar cases within the forum state, i.e., to preserve a minimum of equality. ${ }^{98}$

The controversial question whether treaties for the unification of choice-of-law rules are to be interpreted (if silent on this question) as precluding resort to public policy against foreign law made applicable by such treaties, also would seem to require more than a simple affirmative or negative reply if viewed with this antinomy

such contracts are to be governed by an ad hoc legal system consisting of a synthesis of several national laws, it seems equally appropriate to take into account the economic regulatory legislation of several states. Vischer concedes that all states are entitled to apply the forum's own regulatory legislation, when dictated by local public policy, besides the regulatory legislation of the proper law of the contract. But then it seems unrealistic to overlook the possibility that other states might act in the same manner.

${ }^{90}$ Some authors have sought to draw distinctions between "lois de police contractuelles" such as are to be found in most civilized states, and "lois de police extra-contractuelies" that reflect the economic policy of one particular state in its relation to other states. In our judgment, a more significant distinction can be drawn between prohibitive or regulatory legislation applicable to both single and multipe contact cases, and legislation merely designed to hamper the conclusion of "international" contracts.

${ }^{\circ 7}$ See stipra p. 849 et seq.

${ }^{88}$ Another instructive example of the antinomies produced by the operation of the principle of equality is the following: Suppose the constitution of a state proclaims the equality of men and women. Then, a choice-of-law rule seeking to apply only the husband's national law to legal relations between the spouses would seem inappropriate because it would place the husband in a position to change his nationality and thus to alter the applicable law, see supra p. 83r. If, in view of this objection, the national laws of the two spouses are to be applied alternatively or cumulatively, there will be discrimination between couples of mixed nationality and couples of identical nationality, see stupra note 53 . If, then, a criterion is chosen that avoids this pitfall as well-e.g., the matrimonial domicile-this might lead to the selection of a substantive law that discriminates between men and women (many do). Now, the application of such a law might be excluded by resort to the forum's public policy clause. But finally, if the gap thus created is filled by the lex fori, there will be inequality in the delimitation of the respective scopes of the domestic and foreign legal orders. 
in mind. If such treaties are concluded between a small number of signatory states, it cannot be overlooked that the signatories were familiar with the private law systems of the contracting parties. An undertaking to apply the law of the contracting parties can hardly under these circumstances be interpreted as permitting each participating state to whittle away such an obligation by resort to public policy, at least so far as the law of the contracting parties at the time of the conclusion of the treaty is concerned. Different considerations apply to later, completely novel enactments of one of the signatory states. Still different is the case of multilateral treaties that are open to accession by other states. Here, continued resort to the public policy clause might be deemed to have been tacitly conceded, but there would still probably be a treaty obligation to keep its use against the laws of other contracting states in bounds that would not exist with respect to choice-of-law rules that are unrestricted by treaty obligations. The significance of this obligation will, as a practical matter, naturally depend upon the decisions of an international tribunal that has power to police the performance of the treaty. Just as the public policy clause establishes a ceiling for the application of foreign law within the forum state, treaties for the unification of choice-of-law rules likewise place a ceiling upon resort to public policy. ${ }^{99}$ This reflects the compromise character of a multilateral treaty for the unification of national choice-of-law rules: It can be presumed that even between the antinomial manifestations of the principle of equality, there will be compromise. Such a compromise between the antinomial manifestations of the principle of equality, in turn, would seem to be one of the general principles of private international law.

\footnotetext{
${ }^{00}$ In the Boll case, Sir H. Lauterpacht expressed the view that a state which is a party to a multilateral treaty for the unification of choice-of-law rules and has recourse to ordre public in derogation of the uniform choice-of-law rule "must show that that exception was applied reasonably and in good faith." Case Concerning the Application of the Convention of rgoz governing the Guardianship of Infants (Netherlands v. Sweden), 1958 I.C.J. Reports 55, at 79, 99 (separate opinion). An apparent parallel is posed by the Hague Convention of October 24, 1956, Regarding the Support Claims of Children, which permits the contracting parties to refuse to apply the law chosen by virtue of the convention if this law is "manifestly" contrary to the public policy of the forum.
} 